\title{
Tangut Documents of Household Registrations
}

Chinese historical archives are generally short of information on Tangut social conditions such as demographics, households and families. For this reason, work on Tangut families and populations long remained virtually non-existent. Although it is true that the Revised Laws of Heavenly Prosperity provides generations of scholars with important legislations on Tangut households and families, as a general code of law it could not possibly offer any detail on the social realities in Western Xia. It is in this historiographical context that the more than 100 registers of households and demographic documents, though fragile and fragmented, are celebrated as a breakthrough in the field and are marvelled at for their vast number of primary materials on the demographics of Khara-Khoto.

Household registration, a tradition of more than 2,00o years, may be traced back to the Qin Dynasty, and is said to have matured under the Tang Empire. Chinese household records are oftentimes mentioned in archives but seldom preserved in physical forms. The only exceptions are the Dunhuang and Turpan household registers and self-reports (shoushi), our main sources of knowledge on local demographics from Western Liang to the Five Dynasties. The discoveries of these documents transformed social and economic studies on these areas, and shed light on the evolving history of household registrations over the course of six centuries.

The discovery of Tangut household registers, long unknown to historians, not only fills the gap in knowledge on Tangut household registration itself, but also revolutionizes research on the society and economy of Xia. They also serve as references for the contemporaneous Liao, Song and Jin-the studies of which all suffer a lack of material sources.

\section{Household Registers and Accounts}

Most of the numerous household registers and accounts from Khara-Khoto are today housed at the Institute of Oriental Studies at the Russian Academy of Sciences. Few of them are preserved at the British Museum. Most Tangut household records are written in the cursive or the running script, and are unfortunately only in fragments. 


\subsection{Household Registers}

Tangut manuscripts excavated at Khara-Khoto might not necessarily have been produced in that city. In fact, they are likely to have come from all parts of the empire. The books printed by the Bureau of Character-Carving, for example, were brought over from the capital city Zhongxing (today the city of Yinchuan in Ningxia). But the hand-written social documents - household registers, contracts, accounts, enlistment records, official documents and letters - unlikely to be highly circulated texts, were from local sites of Khara-Khoto, according to the locations indicated on the manuscripts. Инв. No. 2736, an official document by the commander of Khara-Khoto dated to 1224, Инв. No. 2775-6, an official document by the deputy commander of Khara-Khoto, Инв. No. 285126, and another 14 military documents (е.g., Инв. No. 7916), are all labelled "belonging to Khara-Khoto." Likewise, household records and contracts excavated in Khara-Khoto were also locally used and circulated documents.

The Tangut character for "household" is 羓 [ya]. Some fragments of manuscripts seem to suggest that, at least in the city of Khara-Khoto, the Tanguts counted households by the unit of 玈剩 [tśji-. rer], or liliu. The first character means "to move or migrate," and the second, "a line." The term is translated in Chinese as liliu - roughly equivalent to the Chinese li or lijia-according to its definition in Revised Laws of Heavenly Prosperity. Liliu constitutes the basic level of social organization in Western Xia. Households in Khara-Khoto registered under the category of liliu, reporting first the name of the patriarch, then the number of family members in the house, and finally details of their gender, age and relationship to the patriarch, or "head of the household." Инв. No. 4991-4, for example, is a fragment of a liliu register. The 11 lines in total, with some corrections and markings, are handwritten in the Tangut running script on a piece of hemp paper, which is $18 \mathrm{~cm}$ in length and $28.5 \mathrm{~cm}$ in width. ${ }^{1}$

The un-indented first line records the name of the head of the liliu, below which is the population size in each household, and further down, the numbers of males and females, numbers of adults and children, and at last, their own names.

Translation: ${ }^{2}$

1 Russian Collection of Khara-Khoto Manuscripts, vol. 13, p. 322. Lit. "qianliu accounts of poll tax," now translated as "liliu register accounts."

2 Tangut characters are written vertically, from top to bottom. In the following translation, the best approximation is to write the vertical lines horizontally, but have the format and content remain the same. The insertions of "......" represent missing lines. The squares " $\square$ " are missing characters, and the characters inside the $\square$ are inferred from context. The shaded $\square$ suggests that the original characters had been blotted out in the original text. "?" indicates that the character is either unclear or illegible. The same format applies to the translation of 


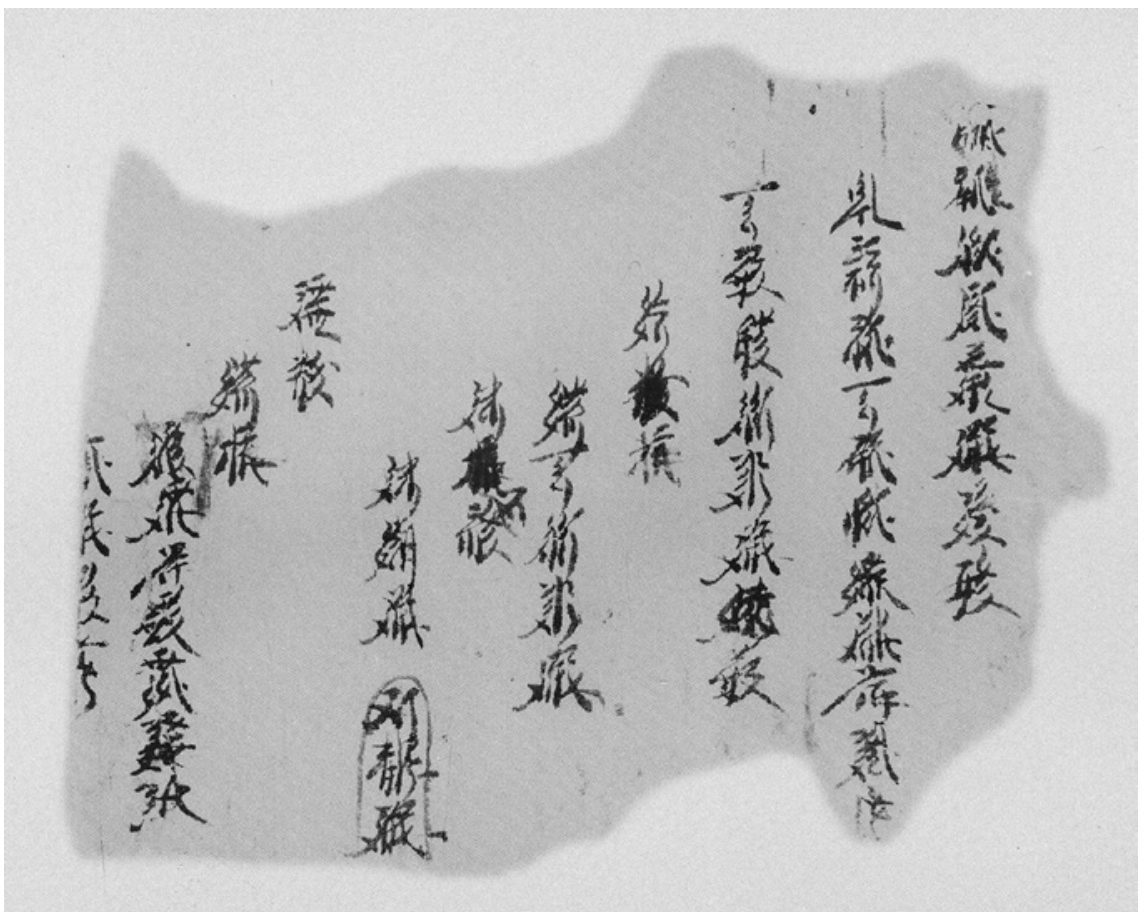

FIGURE 13 Инв. No. 4991-4: Liliu household register

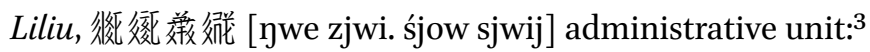

(lit.) dark, lone man, ${ }^{4}$ no livestock, previously, Chen?

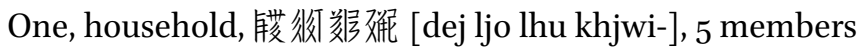

Males, 32

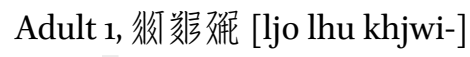

Child 2 1, son

social documents in the rest of the book. For the sake of convenience, the English translation of Tangut names features the Chinese pinyin transcriptions of the Tangut characters, rather than the phonetic symbols designed for Tangut characters by Dr. Gong Hwang-cherng, which are found elsewhere in the book for the specific purpose of introducing phonetics. Some of the transcripts are followed by literal translations of the names in the parentheses, whose meanings are then discussed in the main body of the text.

3 Tangut, 教䑮 [tśju lji.j] in the Fan-Han Pearl in the Palm is literally translated as "department/ bureau, division." Based on its use in multiple Tangut manuscripts, the phrase means an administrative area or division. See also the Russian Collection of Khara-Khoto Manuscripts, vol. 10, p. 15 .

4 The original character is 新 [lu.] (poor, impoverished) or 新 [mjo.] (alone, widowed). Despite morphological similarities to the left, the character as shown and used in the context of the document is best interpreted as the latter. 


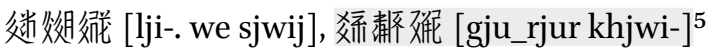 \\ Females 3 \\ Adult 2 \\ Wife, Lady 倠 [ljow] (Liang) 舞钮榎 [mja mji- wejr] \\ Female $\square \square \square{ }^{6}$ \\ Child 1
}

According to Revised Laws of Heavenly Prosperity, a liliu comprises nearly a hundred households. ${ }^{7}$ The head of the liliu referred to in the manuscript above

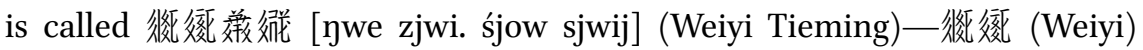
being a prominent Tangut surname. The mentioning of the local "administrative unit" indicates that the territories to be enumerated fall under this man's political authority. Line 2 begins with the name of a special individual in this liliu, the first three words being 倩 [dzjwo] (man), either 稿 [lu.] (lit. poor) or 稿 [mjo.] (alone, single, widowed) — the left part of the character resembles the former, but the latter makes more sense in this context—and 㭽 [nja_] (dark, black). Put together, the name reads, "a dark, lonely man," one without livestock, possibly surnamed Chen, and, because there is no "one household" noted before his name, probably someone who has family members but not a settled house. Then follows the registration of each household. The first line starts with 罗羫 [lew ya] (one household). Unfortunately, only the informa-

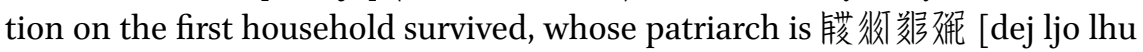
khjwi-]. The man used to be in the company of six family members, but as shown on the manuscript, the number 俢 [tśhjiw] (six) was crossed out and corrected to 㭽 [ywə] (five). One of them was supposedly, and sadly, lost to the family. Likewise, though there used to be three males, as 彭 [so.] (three) was crossed out and updated to 梓 [nji-] (two), only two of them seem to have sur-

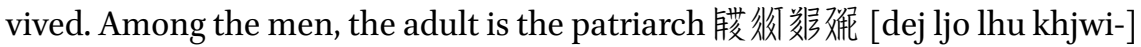
and the child is his son. In the records on the two children, the 梅 [nji-] (two) is updated to 夰 [lew] (one), leaving Xiao Luming (lit. little bright donkey) as the

5 TN: The names of the two children literally mean, "a manifest donkey" and "a lucky dog."

6 The four characters in the 11th line all suffer the loss of their left parts. The first character seems to be the right part of 离沀 [mji.j] (woman). The next three characters are a person's name. And the rest of it is lost. It is inferred from context that the next line is "child, one," followed by the name of the second daughter.

7 See the Revised Laws of Heavenly Prosperity 15, pp. 514-515. There it is translated as qianliu, now corrected to liliu. 
only child, and the name of the second son, Ji Xiang Quan (lit. "blessed dog"), is crossed out. He possibly passed away.

There are three women: the wife of the patriarch, née Liang (maiden name), whose name is Mu Niang Sheng (lit. "prosperous mother"), and their two daughters. The elder daughter is a grown-up (only half a line remains legible), and though the rest of the piece is lost, we infer that the other daughter is still underage. Despite the damages, this register preserves the first page of the liliu record, offering a wealth of information on Tangut household registration.

One of the registers that records rather numerous households is Инв. No. 6342-1, a long roll of considerable width and rich in content. The register, $19.1 \mathrm{~cm}$ long, $312 \mathrm{~cm}$ wide and somewhat damaged in the front, is handwritten in the Tangut running-cursive script on a piece of hemp paper. The three-meter document is divided into two parts-117 lines in the first and 47 lines in the second- 164 lines total. ${ }^{8}$ On this precious manuscript are found the demographics of 30 households.

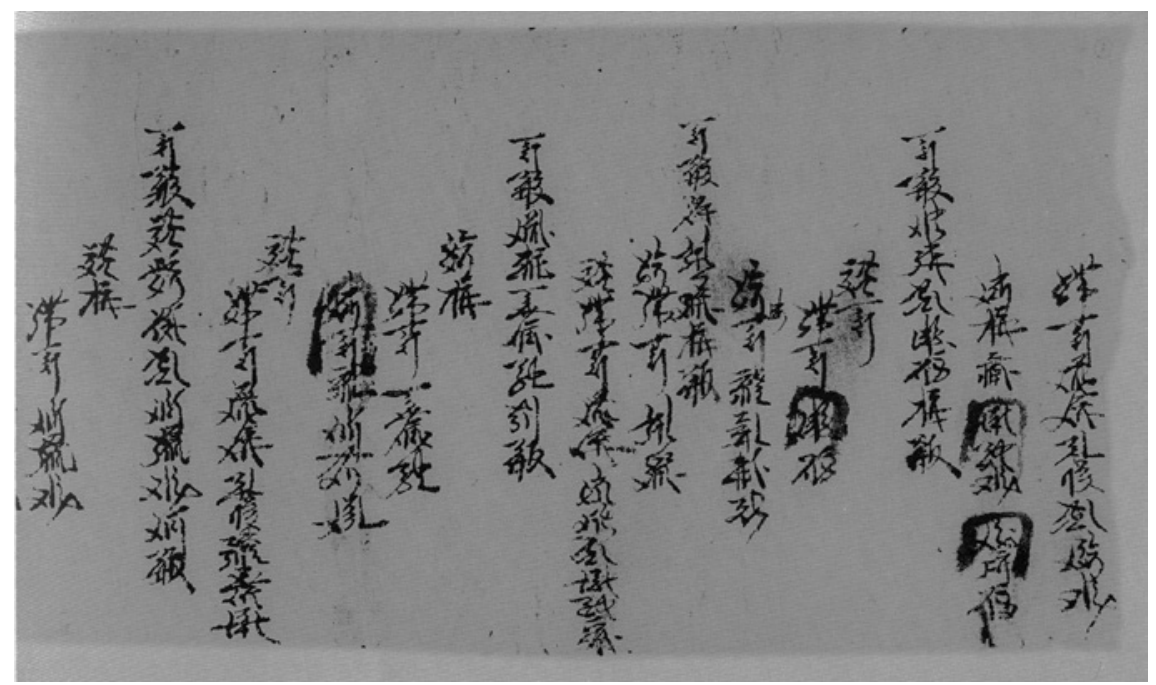

FIGURE 14 Инв. No. 6342-1: Register fragment (1)

8 Russian Collection of Khara-Khoto Manuscripts, vol. 14, pp. 118-123. 


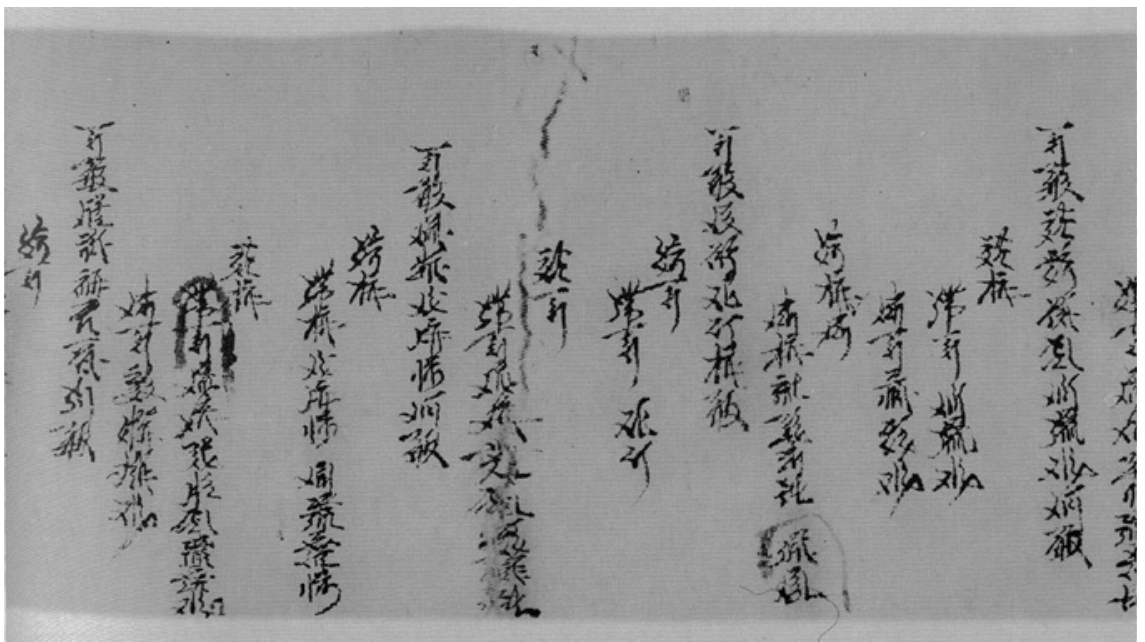

FIGURE 15 Инв. No. 6342-1: Register fragment (2)

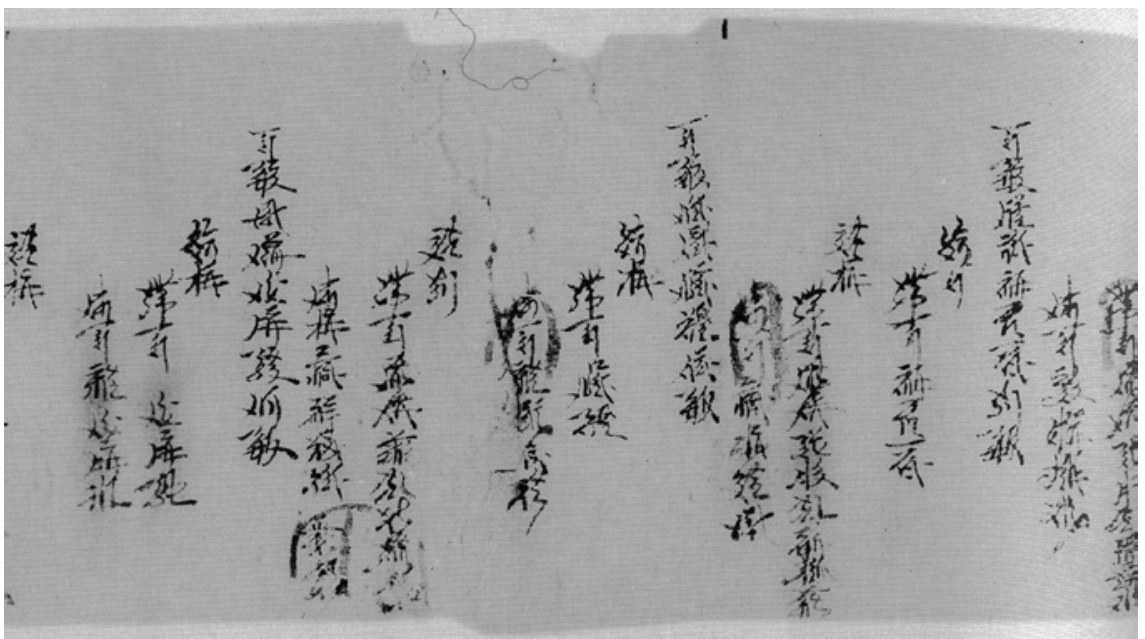

FIGURE 16 Инв. No. 6342-1: Register fragment (3) 


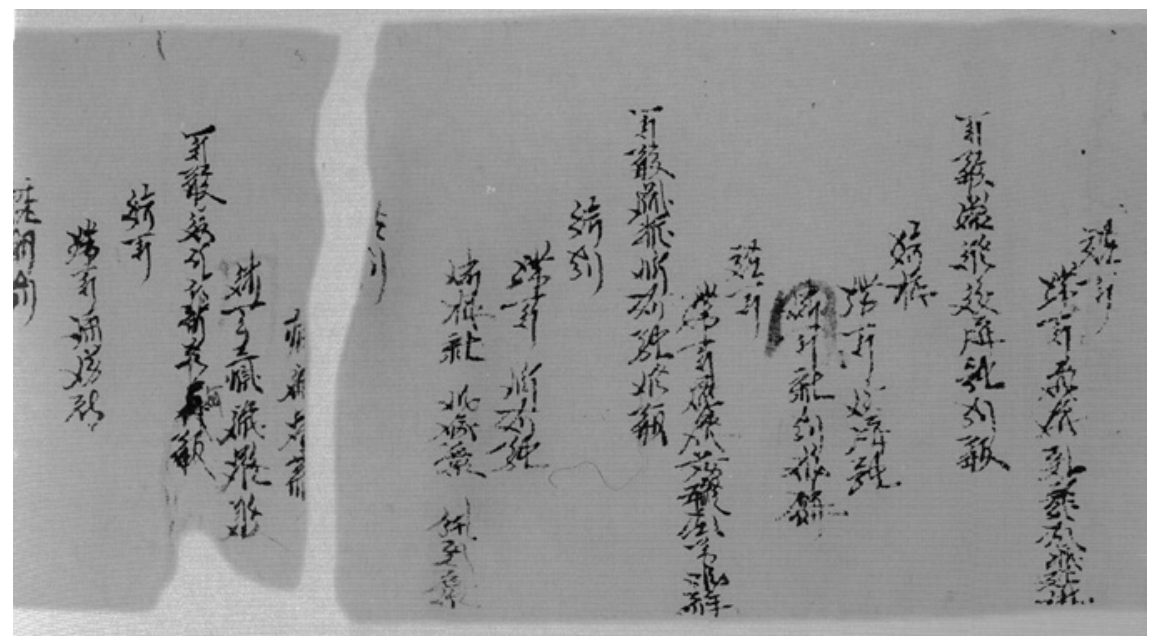

FIGURE 17 Инв. No. 6342-1: Register account (9)

Translation into English: ${ }^{9}$

(one household ......) (1)

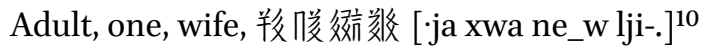

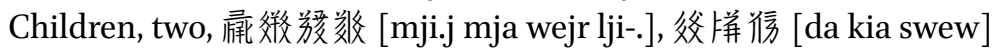

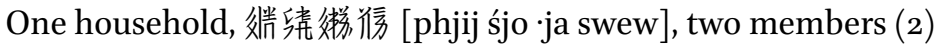

Female, one

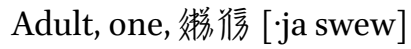

Male, child, one, son, 形乘胗 [zjo. dźjo ·jiw]

One household, 倠 (Liang) (?)﨎 [ljow ne. khjwi-], 2 members (3)

Male, adult, one, (?)难 [ne. khjwi-]

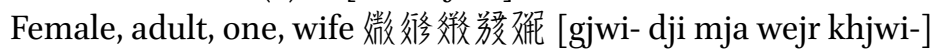

One household, 微䉼录微㔙 [lwor ze śja lhji. wejr], 3 members (4)

Male, two

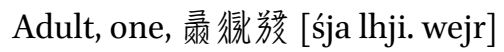

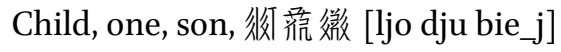

Female, one

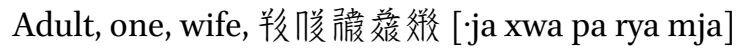

The numbers in the parentheses given on the first line of each household are labels added by the author.

10 TN: lit. "benevolent treasure." 


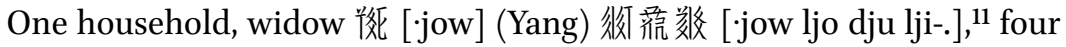
members (5)

Female, two

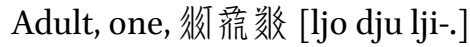

Child, one, daughter, 效 [mju ${ }^{12}$ 敩 [lji-]

Male, two, children

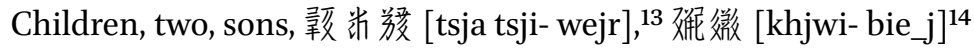

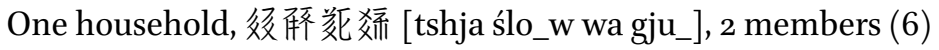

Male, one

Adult, one, 煫效 [wa gju_]

Female, one

Adult, one, wife, née Jiao (㸚 [tsew])???

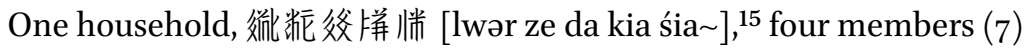

Male, two

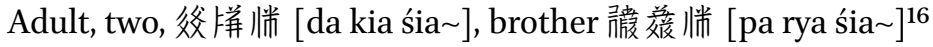

Female, two

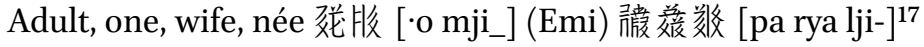

Child, one, younger sister, 㮐摐皱 [lja nji lji-] $]^{18}$

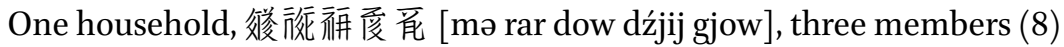

Male, one

Adult, one, 效度离 [dow dźjij gjow]

Female, two

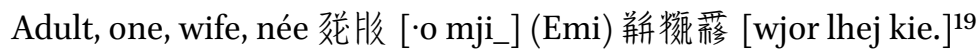

Child, one, daughter, 刘效微 $[1 \mathrm{ji}-. j \mathrm{j} \text { si bie_j] }]^{20}$

11 TN: lit. "blessed with treasure."

12 It is a one-character word in Tangut meaning "brother" (TN: or maternal uncle) commonly used for a woman's reference to her brothers. Here, "the brother's treasure" is the name of the girl.

13 TN: lit. "sister, prosperous" (Chinese edition: "beautiful son").

14 TN: lit. "a joyful dog."

15 TN: lit. "the mountain of/by the old house," etc., depending on how one reversetransliterates 怑.

16 TN: lit. "mountain of wisdom (Prajñā)."

17 TN: lit. "the wise treasure."

18 TN: lit. "treasure of auspicious sign" (㛔嘚 is a fixed expression for auspicious signs and good fortune).

19 TN: lit. "nest, change, gold."

$20 \quad$ TN: lit. "joyful and delighted maiden." 


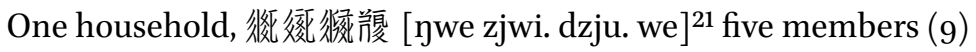

Male, two

Adult, one, 很尝 [dzju. we]

Child, one, son, 很㡾侈 [tśjow lhji. jiw $]^{22}$

Female, three

Adult, one, wife, née 蔽 [la] (Luo) 骰茫 [·jiw dju]

Child, two, daughter, 解行旅恠 [phiow bju nja_] ${ }^{23}$

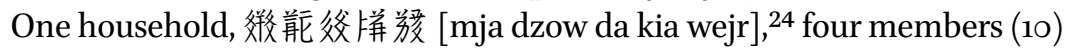

Male, two

Adult, one, 父样聠 [da kia wejr]

Child, one, son, 徐拼敚 [da kia lji- $]^{25}$

Female, two

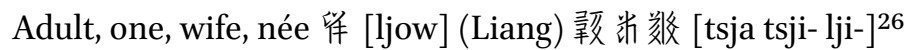

Child, one, daughter, 绞恲致 $[\mathrm{mju}]^{27}$

One household, 㣪带解 [pu. śja phji], two households (11)

Male, one

Adult, one, 带配 [śja phji]

Female, one

Adult, one, wife, 徙䉼 (name)? [lwor ze ? ka]

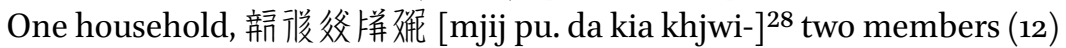

Male, one

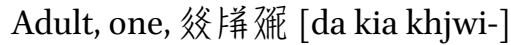

Female, one

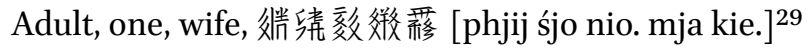

One household, widow, 汧 [xwe ] (Hun), 涤脪 [lji-. mja], three members (13)

Female, one

Adult, one, 敚㸚炎 [lji-. mja]

21 TN: lit. Weiyi "the rainbird."

22 TN: lit. ? (the Year of You/the one born in ...) the first month, depending on how 㫥 is reverse-transliterated.

23 TN: lit. "white, bright, dark."

24 TN: lit. Maze "the prosperity of the old house."

25 TN: lit. "treasure of the old house."

26 TN: lit. "sister, little, treasure."

27 TN: lit. "brother/maternal uncle of the old house."

28 TN: lit. "dog of the old house."

29 TN: lit. "sister/aunt, mother, gold." 
Male, two

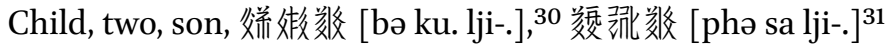

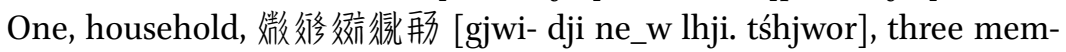
bers (14)

Male, one

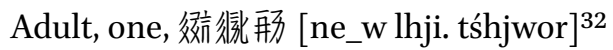

Female, two

Adult, two, mother, 解形殺㸚 [phiow tshji-j lja. mja]

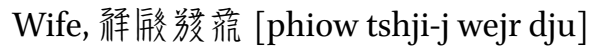

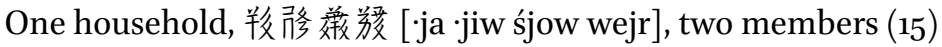

Male, one

Adult, one, 举聠 [śjow wejr]

Female, one

Adult, one, wife, 留影泫解 [ljow tsja tsji- phiow $]^{33}$

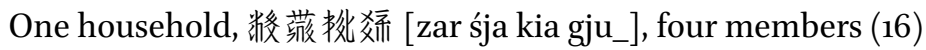

Male, three

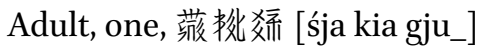

Children, two

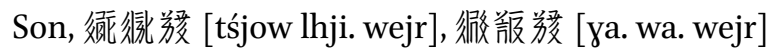

Female, one

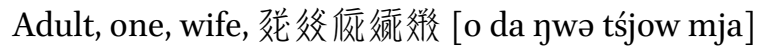

One household, 䑧妍敚 [le tśhjwor lji-.], four members (17)

Male, two

Adult, one, 形单炎 [tśhjwor lji-.]

Child, one

Son, 贍跑 [kia nja_]

Female, two

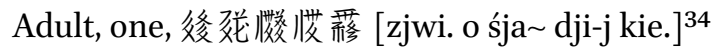

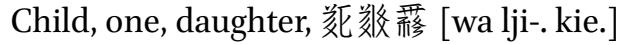

One household, 拜䘡很聠 [le ne_w lhji. wejr], two members (18)

Male one

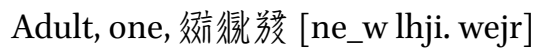

Female, one

Adult, one, wife, 羓唆 [ja xwa $]$...

$30 \quad$ TN: lit. "a treasure behind the pagoda."

$3^{1}$ TN: lit. "Qiang/fan, receive, treasure."

32 TN: lit. "benevolent, month, servant."

33 TN: lit. "white maiden."

34 TN: lit. "Golden Samādhi." 


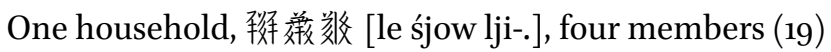

Male, one

Adult, one, 㒸彩 [śjow lji-.]

Female, three

Adult, two

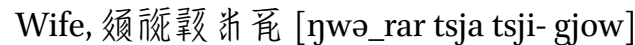

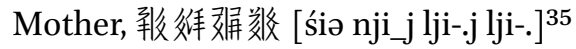

Child, one

Daughter ...

One household, 良夈随胗 [pha lji-. we ·jiw], ${ }^{36}$ two members (20)

Male, one

Adult, one, 䛧效鿴 [lji-. we ·jiw]

Female, one

Adult, one

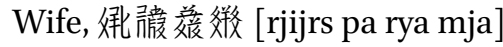

One household, 蔽鍰务谣 [la wejr rjijr pu.], four members (21)

Male, three

Adult, one [菻㥞㣪]

Children, two ...

Female, one, adult, one, wife ...

One household ... two members (22)

Male, one

Adult, one, 藉威㥪 [lu. zji-_r śia $]^{37}$

Female, one, adult, wife 继绕? [phjij śjo ? lji-.]

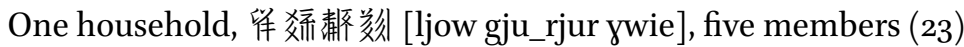

Male, three

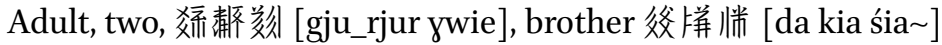

Child, one, son, 兴银儗 [śja. lhji. khjwi-] ${ }^{38}$

Female, two

Adult, two, wife 微䉼解微 [lwor ze phiow bie_j] $]^{39}$

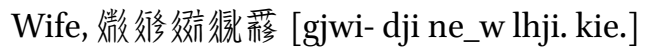

One household, 媺俢茫并爱 [gjwi- dji dju wejr], two members (24)

Male, one

Adult, one, 茫并变 [dju wejr]

TN: lit. "treasure of/with a joyful heart."

36 TN: lit. "the one with a donkey."

37 TN: lit. "joy, water, mountain."

38 TN: lit. "dog of the seventh month."

39 TN: lit. "white and joyful." 
Female, one

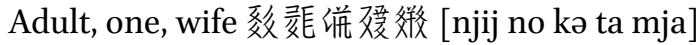

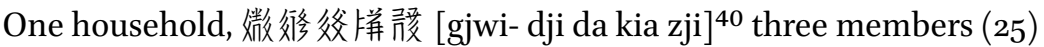

Male, two

Adult, one, 终恲鿏 [da kia zji]

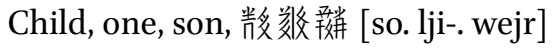

Female, one

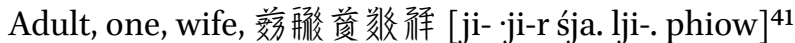

One household, 微䉼得茫営 [lwor ze ljo dju wejr], ${ }^{42}$ six members (26)

Male, three

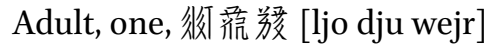

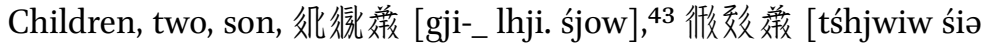
śjow]

Female, three

Adult, two, wife ......

Daughter ...

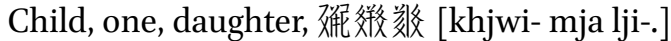

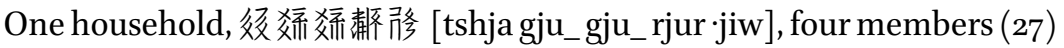

Male, one

Adult, one, 娇糖胳 [ gju_rjur ·jiw]

Female, three

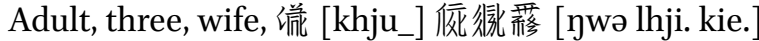

Wife, 倠 (Liang) 㹐滞 [ljow ljo ta]

Daughter, 庰㸚条 [śjow mja]

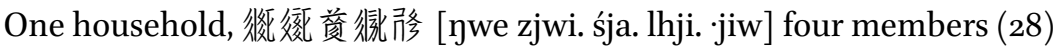

Male, one

Adult, one, 覓很侈 [śja. lhji. jiw]

Female, three

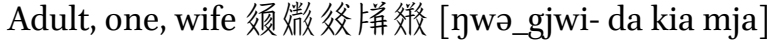

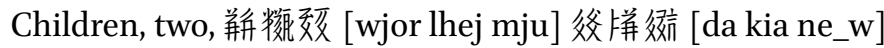

One household, 羓渗鉎刻 [ja xwa wa ywie] two members (29)

Male, one

Adult, one, 敚刻 [wa ywie]

Female, one

Adult, one, wife, 竍㣪很很䔟 [mjij pu. tśjow lhji. kie.]

40 TN: lit. "son/man of the old house."

41 TN: lit. "seven, treasure, white."

42 TN: lit. "the one blessed with great fortune."

43 TN: lit. "iron of the ninth month." 
One household, 倠蔽鼠楼 [ljow lu. zji-_r śia ], two members (30)

The records of 26 out of the 30 households are complete. Household record (1) is damaged on the front, whereas the 3 oth register has lost its end. It is therefore difficult to gain precise numbers on these two families. As for (21), we can still compute the numbers of males and females. Also, that the name of the patriarch on register $(22)$ is lost does not affect our use of the data. The following is the statistics on the 28 households:

CHART 1 Инв. No.6342-1: household registers and demographics

\begin{tabular}{|c|c|c|c|c|c|c|c|}
\hline \multirow[t]{2}{*}{ No. $634^{-1}$} & \multirow{2}{*}{$\begin{array}{l}\text { Total } \\
\text { numbers }\end{array}$} & \multicolumn{3}{|l|}{ Male } & \multicolumn{3}{|c|}{ Female } \\
\hline & & Total & Adult & Child & Total & Adult & Child \\
\hline (2) & 2 & 1 & & 1 & 1 & 1 & \\
\hline (3) & 2 & 1 & 1 & & 1 & 1 & \\
\hline (4) & 3 & 2 & 1 & 1 & 1 & 1 & \\
\hline (5) & 4 & 2 & & 2 & 2 & 1 & 1 \\
\hline (6) & 2 & 1 & 1 & & 1 & 1 & \\
\hline$(7)$ & 4 & 2 & 2 & & 2 & 1 & 1 \\
\hline (8) & 3 & 1 & 1 & & 2 & 1 & 1 \\
\hline (9) & 5 & 2 & 1 & 1 & 3 & 1 & 2 \\
\hline$(10)$ & 4 & 2 & 1 & 1 & 2 & 1 & 1 \\
\hline$(11)$ & 2 & 1 & 1 & & 1 & 1 & \\
\hline$(12)$ & 2 & 1 & 1 & & 1 & 1 & \\
\hline (13) & 3 & 2 & & 2 & 1 & 1 & \\
\hline (14) & 3 & 1 & 1 & & 2 & 2 & \\
\hline$(15)$ & 2 & 1 & 1 & & 1 & 1 & \\
\hline$(16)$ & 4 & 3 & 1 & 2 & 1 & 1 & \\
\hline$(17)$ & 4 & 2 & 1 & 1 & 2 & 1 & 1 \\
\hline$(18)$ & 2 & 1 & 1 & & 1 & 1 & \\
\hline$(19)$ & 4 & 1 & 1 & & 3 & 2 & 1 \\
\hline$(20)$ & 2 & 1 & 1 & & 1 & 1 & \\
\hline$(21)$ & 4 & 3 & 1 & 2 & 1 & 1 & \\
\hline$(22)$ & 2 & 1 & 1 & & 1 & 1 & \\
\hline$(23)$ & 5 & 3 & 2 & 1 & 2 & 2 & \\
\hline$(24)$ & 2 & 1 & 1 & & 1 & 1 & \\
\hline$(25)$ & 3 & 2 & 1 & 1 & 1 & 1 & \\
\hline
\end{tabular}


CHART 1 Инв. No.6342-1: household registers and demographics (cont.)

\begin{tabular}{lllccccc}
\hline No. 6342-1 & $\begin{array}{l}\text { Total } \\
\text { numbers }\end{array}$ & Male & & & Female & \\
& & Total & Adult & Child & Total & Adult & Child \\
\hline$(26)$ & 6 & 3 & 1 & 2 & 3 & 2 & 1 \\
$(27)$ & 4 & 1 & 1 & & 3 & 3 & \\
$(28)$ & 4 & 1 & 1 & & 3 & 1 & 2 \\
$(29)$ & 2 & 1 & 1 & & 1 & 1 & \\
Total & 89 & 44 & $\mathbf{2 7}$ & $\mathbf{1 7}$ & $\mathbf{4 5}$ & $\mathbf{3 4}$ & $\mathbf{1 1}$ \\
\hline
\end{tabular}

As shown in the table above, there is a total population of 89 living in 28 households, or 3.18 per house, on average. These are relatively small families. There are 44 males and 45 females - almost a 1:1 ratio. With 61 adults and 28 children, there are 2.2 times as many grown-ups as there are underage residents. It is by no means a large population of children.

Other relatively small register fragments, with few households recorded, have also been found. But they do reflect the demographics in the area. An example is Инв. No. 4761-4, handwritten on hemp paper, damaged both in the front and at the end, $17.7 \mathrm{~cm}$ long and $43.5 \mathrm{~cm}$ wide. With some markings, crossings and corrections, the record features 27 lines of Tangut in the running script concerning the registration of only four households. ${ }^{44}$

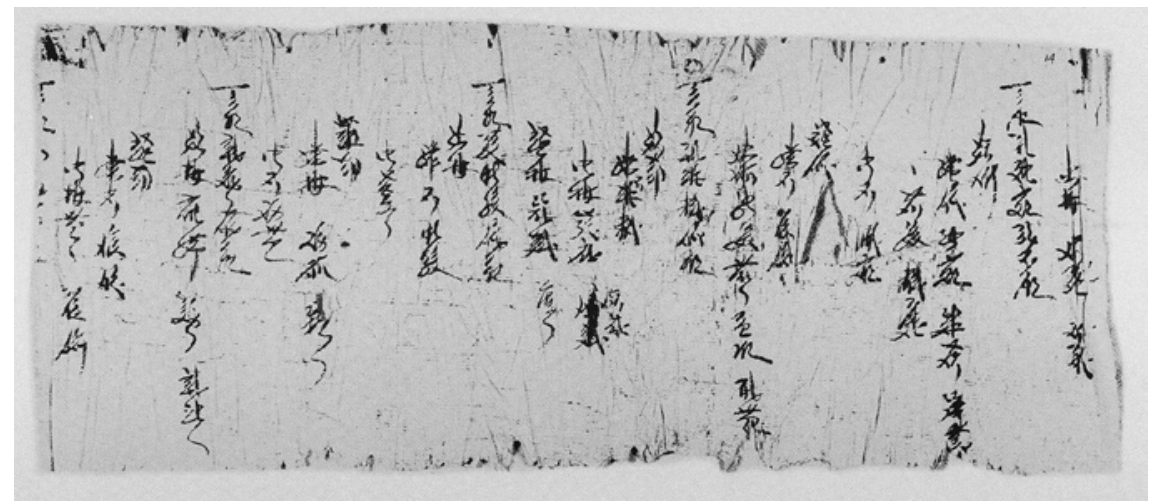

FIGURE 18 Инв. No. 4761-4: Register fragment

44 Russian Collection of Khara-Khoto Manuscripts, vol. 14, p. 273. 
Each register begins with the name of the patriarch and size of the family, followed by the numbers of males and females in the line below, and finally, the numbers and names of adults and children further down in the last lines.

Here are the statistics on the registered households:

CHART 2 Инв. No. 4761-4: demographic data

\begin{tabular}{lccccccc} 
No. 4761-4 & $\begin{array}{l}\text { Population } \\
\text { size }\end{array}$ & Male & & \multicolumn{5}{c}{ Female } \\
& & Total & Adults & Children & Total & Adults & Children \\
\hline$(1)$ & 11 & 6 & 5 & 1 & 5 & 1 & 4 \\
$(2)$ & 5 & 3 & 1 & 2 & 2 & 2 & \\
$(3)$ & 5 & 2 & 1 & 1 & 3 & 2 & 1 \\
$(4)$ & 5 & 2 & 2 & & 3 & 1 & 2 \\
Total & $\mathbf{2 6}$ & $\mathbf{1 3}$ & $\mathbf{9}$ & $\mathbf{4}$ & $\mathbf{1 3}$ & $\mathbf{6}$ & 7 \\
\hline
\end{tabular}

As shown in Khara-Khoto No. 4761-4, one of the four households is as large as 11 in size, while the other three have five members each. The four households have 26 residents in total, about 6.5 per house. There are 13 males and 13 females, in a perfect 1:1 ratio. In contrast to the first set of registers, the children here make up a larger proportion: for the 15 adults, there are 11 children.

Another register fragment is the Khara-Khoto manuscript Инв. No. 4761-5, written on hemp paper, damaged in the front and in the back, and measuring $17.7 \mathrm{~cm}$ in length and $34.5 \mathrm{~cm}$ in width. There are 22 lines of Tangut in the

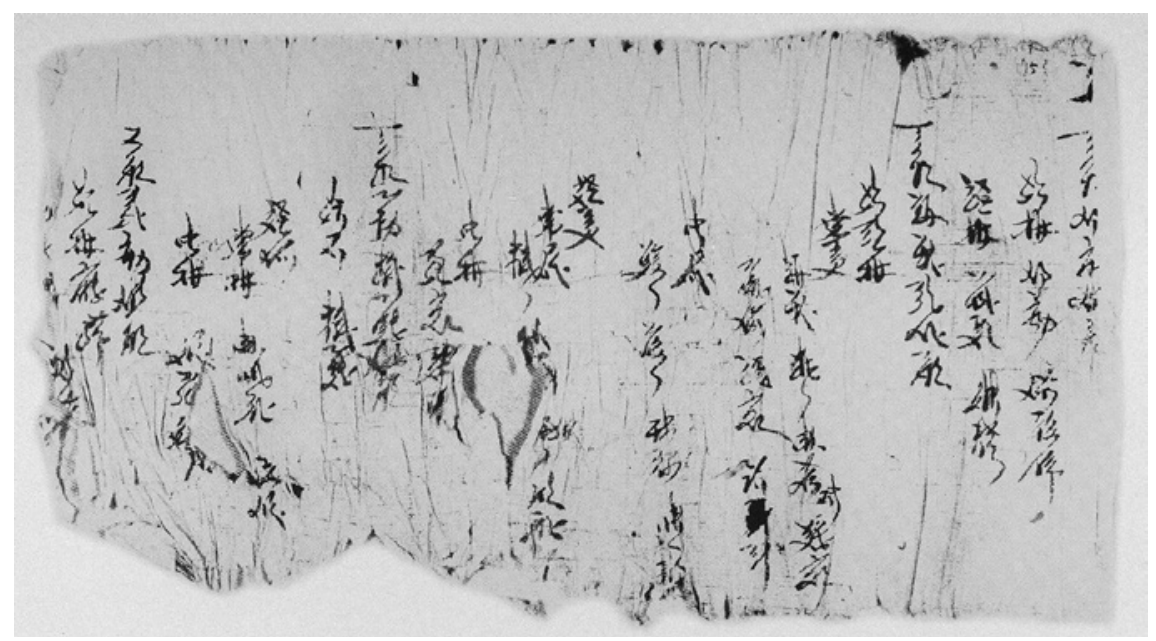

FIGURE 19 Инв. No. 4761-5: Register fragment 
cursive script. It also has data on four households, though the record on the last one is damaged. ${ }^{45}$

This household register is similar in form to the previous one. Here is a table of its demographics:

CHART 3 Инв. No. 4761-5: demographic statistics

No. 4761-5 Population Male Female

Total Adults Children Total Adults Children

$\begin{array}{lrrrrrrr}(1) & 4 & 2 & 2 & & 2 & 2 & \\ (2) & 19 & 12 & 7 & 5 & 7 & 5 & 2 \\ (3) & 5 & 1 & 1 & & 4 & 2 & 2 \\ (4) & 6 & 2 & 2 & & 4 & 2 ? & 2 ? \\ \text { Total } & 34 & 17 & 12 & 5 & 17 & 11 & 6\end{array}$

As shown in No. 4761-5, there are three families of four, five and six members, respectively. One household is quite large, with 19 members. The total population living in the four houses is $34-$ on average, 8.5 per family - a large number, indeed. There are 17 men and 17 women, also in a perfect 1:1 ratio. However, there are only 11 children for the 23 adults, or 2.1 times more adults than children.

From all of this demographic data, it is fair to conclude that at least in Khara-Khoto, small families dominated local communities. Still, there were occasionally prosperous families of more than 10 members as well, like the one large enough to house almost 20 members at the same place. Curiously, it happens to be the case that in the two fragments analysed above, the number of males equals that of females. Perhaps the male-female ratio at the local level was indeed in balance. But of course, we couldn't responsibly make that statement without assembling more demographic data.

\section{$1.2 \quad$ Household Accounts}

Next to the register above is a fragmented page labelled Инв. No. 6342-2. Although physically broken off from Инв. No. 6342-1, the two are inferred to have once been attached to each other, given their uniform paper material, writing style and shared peculiarities of cursive script. This piece functions as the statistical summary of the previous register. It could therefore be seen as 
an account. Also written on hemp paper, it is identical in size to the previous one: $19.1 \mathrm{~cm}$ in height and $64.7 \mathrm{~cm}$ in length. There are 21 lines of Tangut in the cursive script, accompanied by markings and signatures. ${ }^{46}$

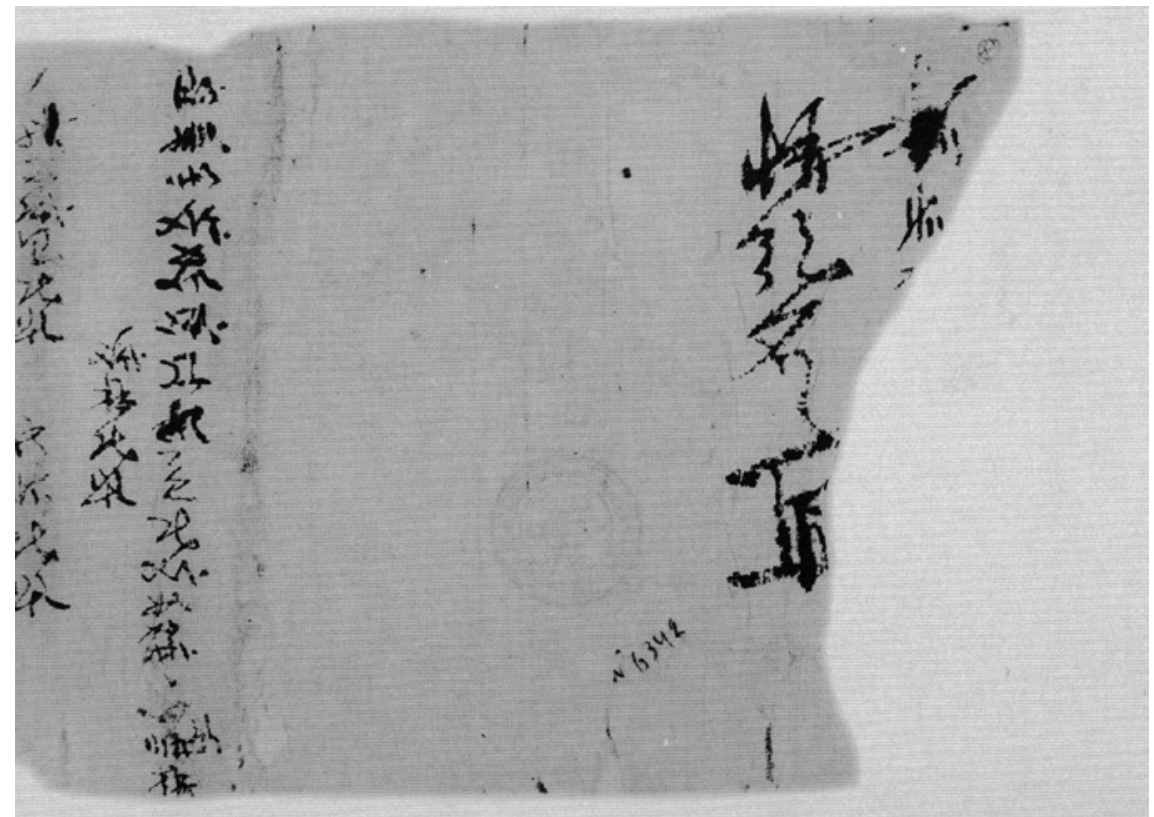

FIGURE 20 Инв. No. 6342-2: Register account (1)

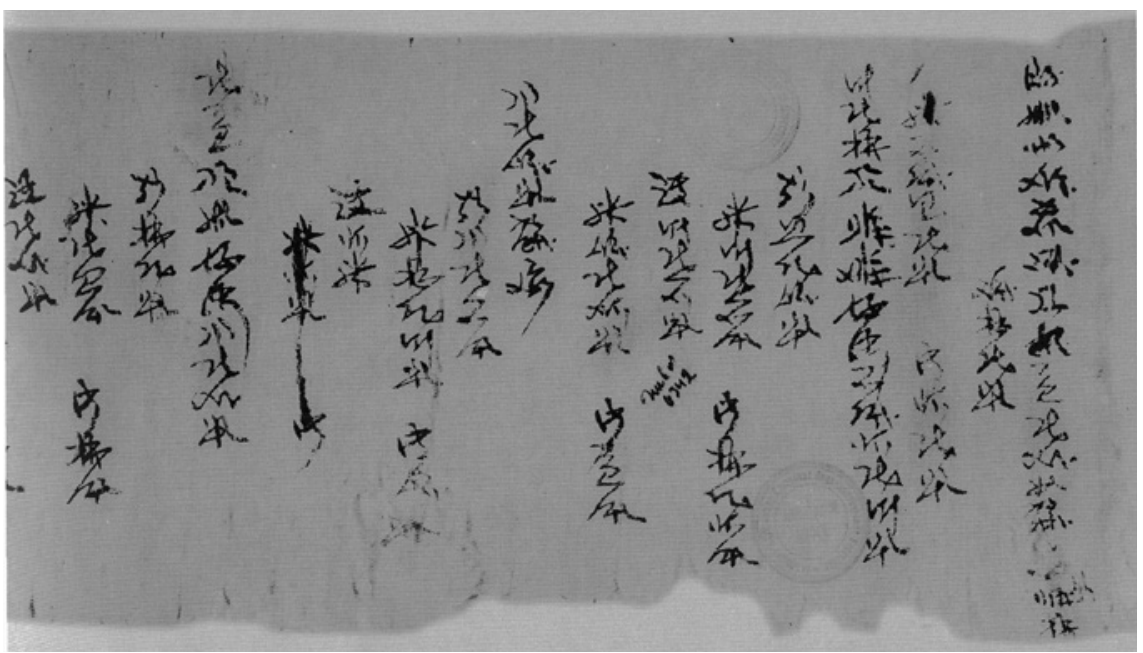

FIGURE 21 Инв. No. 6342-2: Register account (2)

46 Russian Collection of Khara-Khoto Manuscripts, vol. 14, pp. 123-124. 


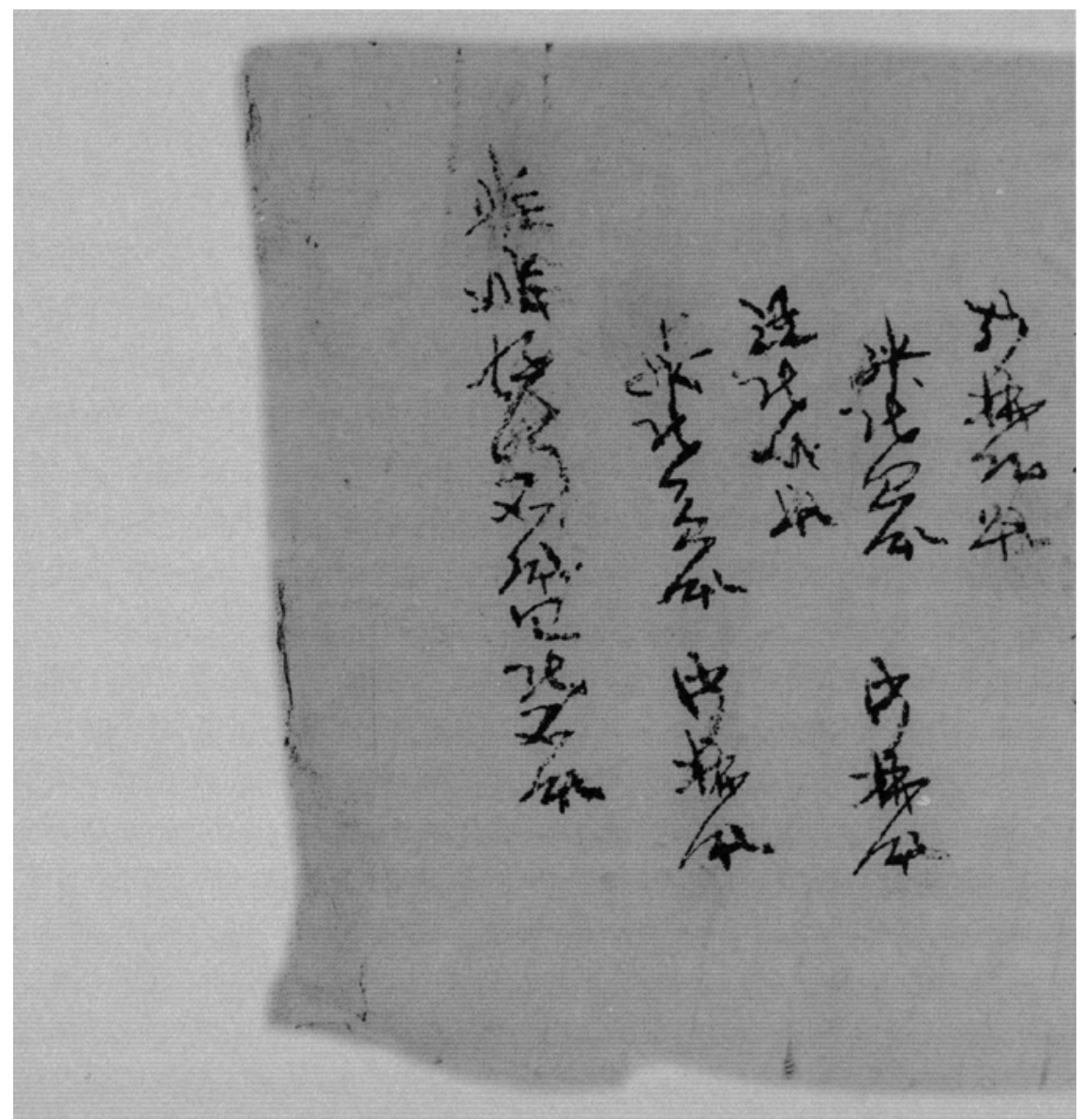

FIGURE 22 Инв. No. 6342-2: Register account (3)

Here is an English translation of the account:

Twenty-one (in large characters, with signature)

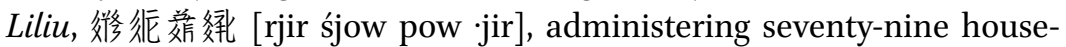
holds?? In total two

Hundred and twenty persons

Adults, one hundred and eighty persons, children, forty persons Sixty-two households, original size, adults and children one hundred forty-six persons

Males eighty-five persons

Adults sixty-one persons, children twenty-four persons 
Females, sixty-one persons

Adults, fifty-four persons, children, seven persons

Thirty-five persons single

Male, thirty-one persons

Adults, twenty-six persons, children five persons

Females, four, adults

Seventeen households? Adults and children, forty-nine

Males, twenty persons

Adults, eighteen persons, children, two persons

Females, nineteen persons

Adults, seventeen persons, children, two persons

Adults and children, one hundred eighty-one persons

We now know that the long roll Инв. No. 6342-1 records 79 households-much more than just 30 -and all fall under the administrative authority of one liliu. In Sui and Tang times, Tangut communities still retained traits of tribal organizations. ${ }^{47}$ Revised Laws of Heavenly Prosperity establishes specific legislations for local communities:

Under proper leadership, all landed households should gather by the proximity of distance: Ten households form a small unit under the local administration of jia, and five small jia units come under a junior supervisor, two of whom are under the authority of a rural liliu. The commands should be given to excellent and leisurely individuals in the positions of junior officials, local bureaucrats, junior administrators, standard soldiers and assistant soldiers. ${ }^{48}$

The owners of the "landed households" are patriarchs of the "taxable households" - peasant families in possession of arable lands and obliged to pay land levies. The "jia, small supervisory unit, and rural liliu" is a tripartite organisation of Tangut rural communities. One rural liliu is placed in charge of two small supervisory units, 10 jia and about 100 households. This complex structure demonstrates that Tangut rural villages were ruled and regulated at multiple levels in systematic governance.

Although Tangut rural communities are scarcely mentioned in Chinese sources, their eastern neighbours are keen to understand the basic organisation of the Tangut military, for obvious reasons. According to Song accounts

47 Old Book of Tang, Bk. 198: History of Dangxiang Qiang.

48 Revised Laws of Heavenly Prosperity 15, pp. 514-515. 
and analyses, Tangut soldiers "under the command of the generals of the chief are referred to as one liu."49 It is also said that "each family in the tribe is called a tent; a male above fifteen years of age, or ding, may be enlisted. Of two such men, one is chosen as a 'standard soldier,' the other a 'bearing soldier,' and the two make a unit of chao."50 It seems that liu in the military sense is in some way related to liliu. It could be that the rural "liliu" in times of peace was turned into the "military liu" when the Tanguts were at war. ${ }^{51}$

Manuscript Инв. No. 6342-2 proves the existence of the rural liliu. As shown in this account, Raoshang Banbai (俢抳获线 [rjir śjow pow -jir]) is in charge of this liliu of only 79 households. This means that "10o households per liliu" was no more than a principle established by the government. The actual numbers of families under the authority of one liliu varied on a case-by-case basis. Oftentimes, the numbers were smaller than prescribed in the laws.

A register account fragment in the manuscript Инв. No. 4384-9 features texts written in the cursive script on both sides of the hemp paper, which are unfortunately illegible due to water stain. Damaged in the front, it is $20.7 \mathrm{~cm}$ in length and $24.7 \mathrm{~cm}$ in width. Of the 14 lines in cursive Tangut, 1-10 are records of four households, and the 11th contains four un-indented characters, "ten houses, one jia," followed by details on each family. ${ }^{52}$

And there is also Инв. No. 4762-3, a list of names of all residents in their own jia in one liliu. Damaged both at the front and at the end, it is handwritten on a hemp paper $20.2 \mathrm{~cm}$ long and $43.2 \mathrm{~cm}$ wide, with 23 lines in the Tangut cursive style. ${ }^{53}$

Six jia are listed in this document, each one preceded by the character 婓 [kia] (jia) and followed by series of names. The first name after “找” should be the administrator of the jia, the others being members of the group. Some jia communities noted their locations, though the last jia is partly lost. There are around 1o persons in each of the first five jia. This document reveals that rules in the Revised Laws of Heavenly Prosperity concerning households, jia, and liliu were basically enforced in practice.

49 Zizhi Tongjian vol. 132, First year of Qingli Era, Emperor Ren of Song (1041), Jiazi, fifth and twelfth months.

50 Zeng, Gong (曾鞤: 1019-1083). Long Ping Ji [隆平集] Bk. 20. “On Foreign States” Wenyuange Sikuquanshu edition (文淵閣四庫全書本). Rpt. Beijing: Airusheng, 2009; Taipei: Taiwan Commercial Press, 1983, Bk. 20, "On Foreign States."

TN: A soldier carries provisions and weapons for his partner in the same chao. For more on the military \& civil organisations of liu of Western Xia, see Shi, Jinbo; (transl.) Li, Hansong. Tangut Language and Manuscripts: An Introduction. Leiden: Brill, 2020, pp. 23-24, 452, 474, 476 (military); 21, 452, 469-471, 500 (civil).

$5^{2} \quad$ Russian Collection of Khara-Khoto Manuscripts, vol. 13, p. 209.

53 Russian Collection of Khara-Khoto Manuscripts, vol. 13, p. 277. 


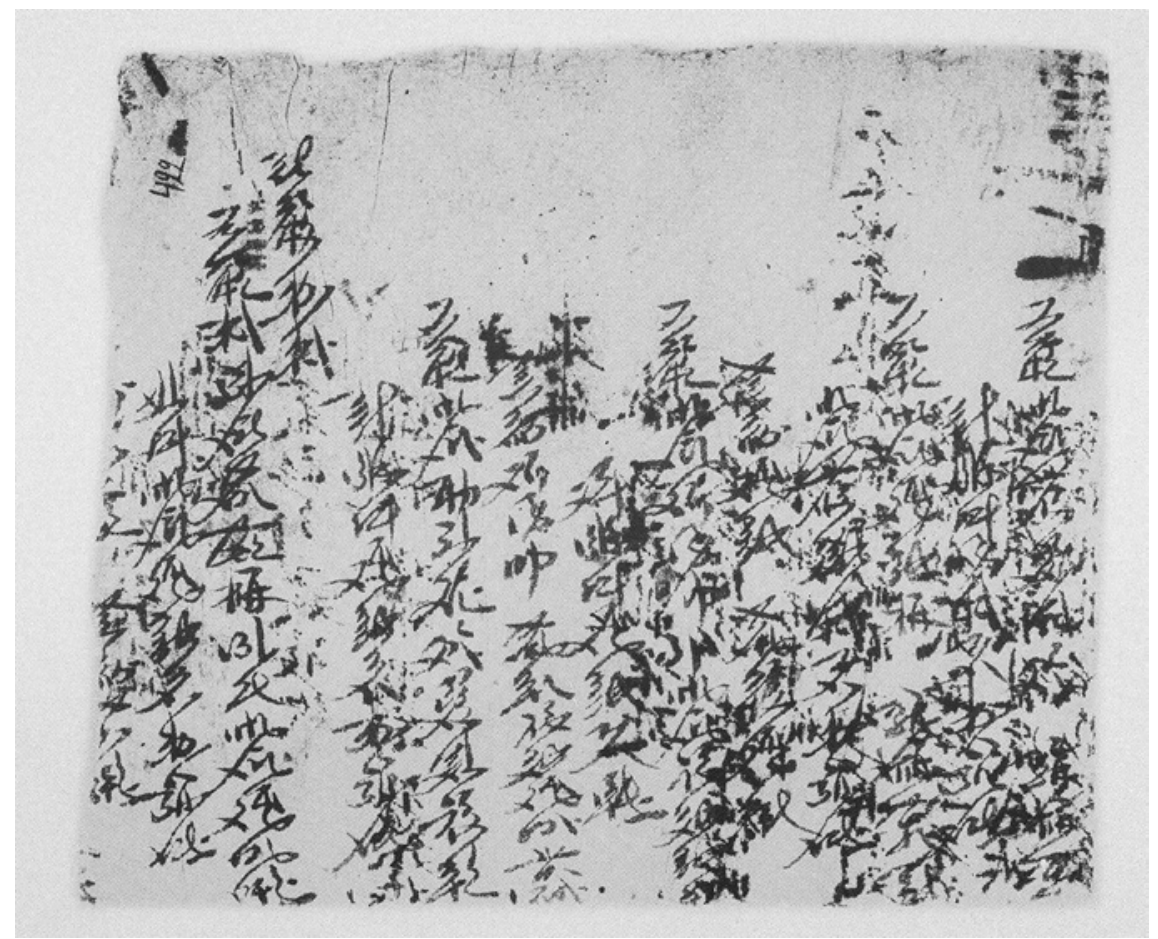

FIGURE 23 Инв. No. 4384-9:Jia register accounts fragment

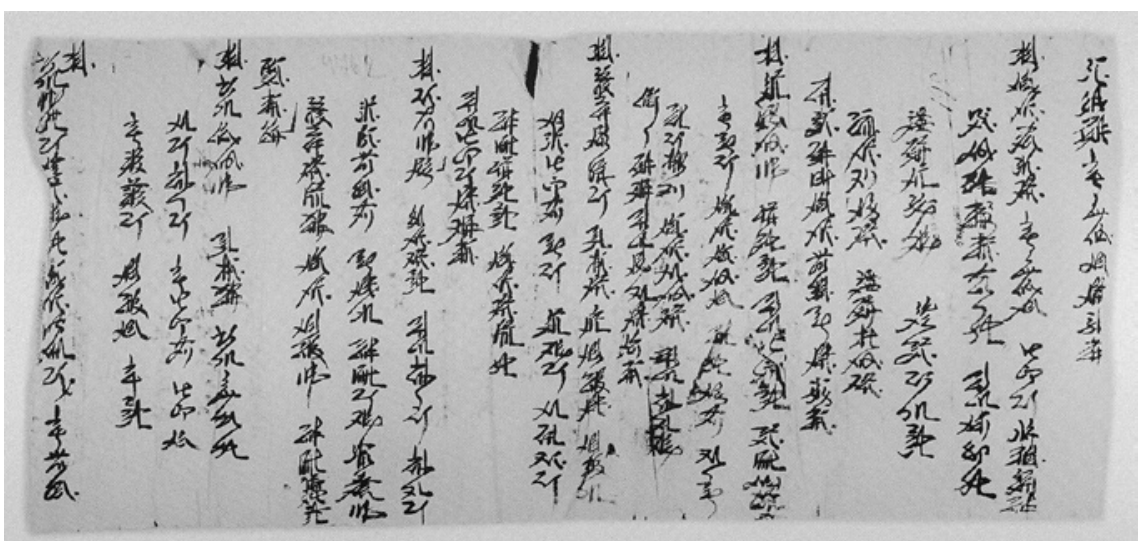

FIGURE 24 Инв. No. 4762-3: Liliu jia list of household registers 
In ancient China, rural villages never constituted a level of government. The imperial dynasties chose not to rule at the bottom level in order to reduce both governmental expenditure and the burden on local peasants. The Tanguts also adopted this measure and made some adjustments to their own conditions. We know from the Tangut laws that liliu is not actually a governmental agency, but a self-governed organisation of communities under the guidance of the government. Those in charge of a liliu were not experienced, government-appointed officials, but men with some governing skills chosen from amongst the folks. In the Tang Dynasty, a hundred households made a $l i$ [里] and five li formed a xiang [鄉]. ${ }^{4}$ During the Song Dynasty, the xiang-li, still in use in the early period of Song, gradually evolved into the bao-jia system, which dominated the scene in mid and later Song. Under the latter system, 1o households constitute one bao: 50 houses are one dabao, and 500 a dubao. As time went on, a bao shrank to five, a dabao to 25, and one dubao to 250 households. Each bao is headed by an elder, and a dubao by an officer and a deputy officer..$^{55}$ There is little doubt that the organisation of local communities in the Tangut Empire was borrowed from the Chinese xiang-li system and, after the legal reforms of Northern Song, the bao-jia laws. Furthermore, the Tangut character 叛 [kia] is almost phonetically identical to the Chinese jia 甲. It is reasonable to surmise that the concept of kia, a transliterated word, had been unknown to the Tanguts until it was introduced from the Central Plains to the northwest.

The socio-political functions of the xiang-li system in China expanded over time. The bao-jia was responsible for monitoring demographic changes in rural areas, compiling household registers, and overseeing the levy of taxes. Likewise, the Tangut liliu assumed expansive roles. It registered the households, lands, livestock and other properties, compiled and reported the accounts from the area, commissioned and coordinated the building and repairing of canals. Another important role of the Tangut liliu was registering and managing junchao, the basic units of the Tangut military. This function, unique to the Tanguts and unheard of elsewhere in China, was closely linked to the Tangut institution of enlistment at that time. ${ }^{56}$

54 Old Book of Tang, Book 43, 2: Bureaucratic System.

55 History of Song, 192, 6: Military System.

$5^{6}$ Shi, Jinbo. “Xixiawen Junji Wenshu Kaolue: Yi Ecang Heishuicheng Chutu Junji Wenshu Weili” [西夏文軍籍文書考略: 以俄藏黑水城出土軍籍文書為例]: “Studies on Tangut Military Records: Taking the Military Records from the Russian Collection of Khara-Khoto Manuscripts as Examples" in Zhongguoshi Yanjiu [中國史研究]:Journal of Chinese Historical Studies, issue 4, 2012. 
As shown in the register account Инв. No. 6342-2, there was a population of 146 amongst the 79 households (previously 62 ), and 35 were single. ${ }^{57}$ The latter 17 houses are recorded to have 49 men and women, but a quick addition of the numbers yields 39 instead of 49 . It could be an error that the Tangut "three" was written as "four." But in any case, the total population of this liliu should be 220. The "singles," as illustrated above, are a special group, both included in the total number and excluded from the 79 households. They might be similar in status to the "dark, poor man" mentioned in No. 4991-5: he roams the area, without a household or settlement. One possibility is that they were shijun or nupu slaves who had not achieved full status as free men. ${ }^{58}$ Whichever case it is, the seemingly homeless Tanguts revealed in this document are worth further study. The final line notes that originally there were 181 adults and children, exactly the sum of the 146 persons in the original 62 households and the 35 singles. Again, it suggests that the 17 households were later added to the list. As for where the additional families were from and why they were listed separately from the original 62 households, we do not have a clue. But it is the case that the household registers found in Dunhuang also distinguished new from old households.

The average household size in this rural liliu is less than three: These are notably small families. There are 180 adults and 40 children-not a community of many children. Amongst the residents, there are 136 men and 84 women, a ratio of 1.62:1. Compared to other registers, the men in this place are out of proportion, and definitely beyond the limit that is required for sustainable social development. But amongst the individuals of single status, there are 31 males and only 4 females, an enormous difference that greatly affected the overall male-to-female ratio of the population. If, for a moment, we disregard the outlying data points of the 35 singles, the male-to-female ratio drops to 1.2:1. And if we only take the numbers of adult males ( 61 men in 62 households) and females ( 54 women in 62 households), the ratio turns out to be even closer: 1.13:1. At last, among the 17 new households, there are 20 adult males and 19 adult females, with a ratio of 1.05:1. In short, with a more rigorous approach and a sufficiently narrow scope of analysis, the male-to-female ratio appears more in order.

Additionally, there are some register fragments that also deal with statistics on households. Инв. No. $7893^{-18}$ is a list of names of individuals under the

57 Single status in Tangut is 睋绿 [ta śji ], transliteration of the Chinese: 单身.

$5^{8} \quad$ Revised Laws of Heavenly Prosperity 12, p. 417; 20, p. 606. 
administration of a particular liliu..$^{59}$ Инв. No. 5949-41 and Инв. No. 7922 are lists of names under the authority of a lizheng (commander in charge of a li). ${ }^{60}$

\section{$2 \quad$ Household Self-Reports (Shoushi)}

In the tradition of Tang and Song local administrations, residents would report their own demographics, land ownership and burden of taxation to the government in self-declared documents that we call shoushi. Tangut shoushi, or 'self-reports,' constitute a part of the corpus of Tangut social documents. For example, manuscript Инв. No. $7629-1$ is the record of a rather large family. It is written on hemp paper, $19.9 \mathrm{~cm}$ long and $50 \mathrm{~cm}$ wide, with 28 lines in Tangut: 25 lines of main text, and 3 lines in a smaller font, noting the ages of the individuals next to their name. ${ }^{61}$

We are also surprised to find a piece of self-report written in the Tangut running-standard script: the manuscript Инв. No. 8203, which happens to be the fair copy of 7629-1 (reproduced for more clarity). It is also written on hemp

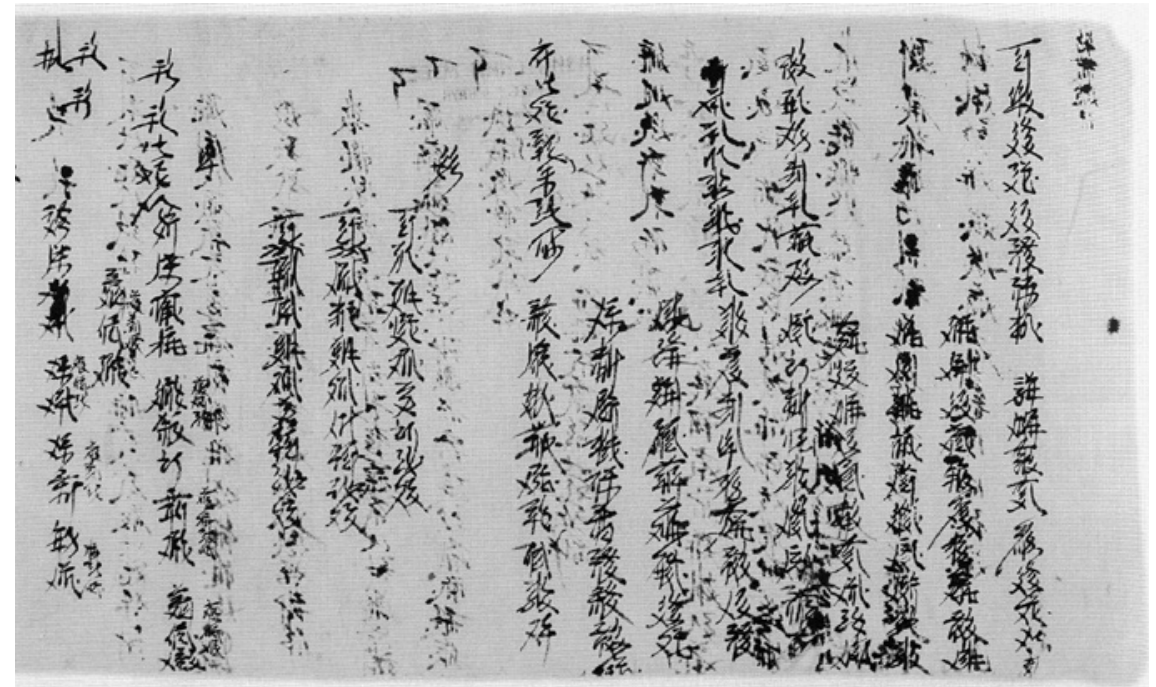

FIGURE 25 Инв. No. 7629-1: Self-reports (shoushi) (1)

59 Russian Collection of Khara-Khoto Manuscripts, vol. 14, p. 217.

6o Russian Collection of Khara-Khoto Manuscripts, vol. 14, pp. 100, 227. In Tangut and Chinese, the term means "commander in charge of $l i$," i.e. a person who has authority over the households within the range of a liliu.

61 Russian Collection of Khara-Khoto Manuscripts, vol. 14, pp. 183-184. 


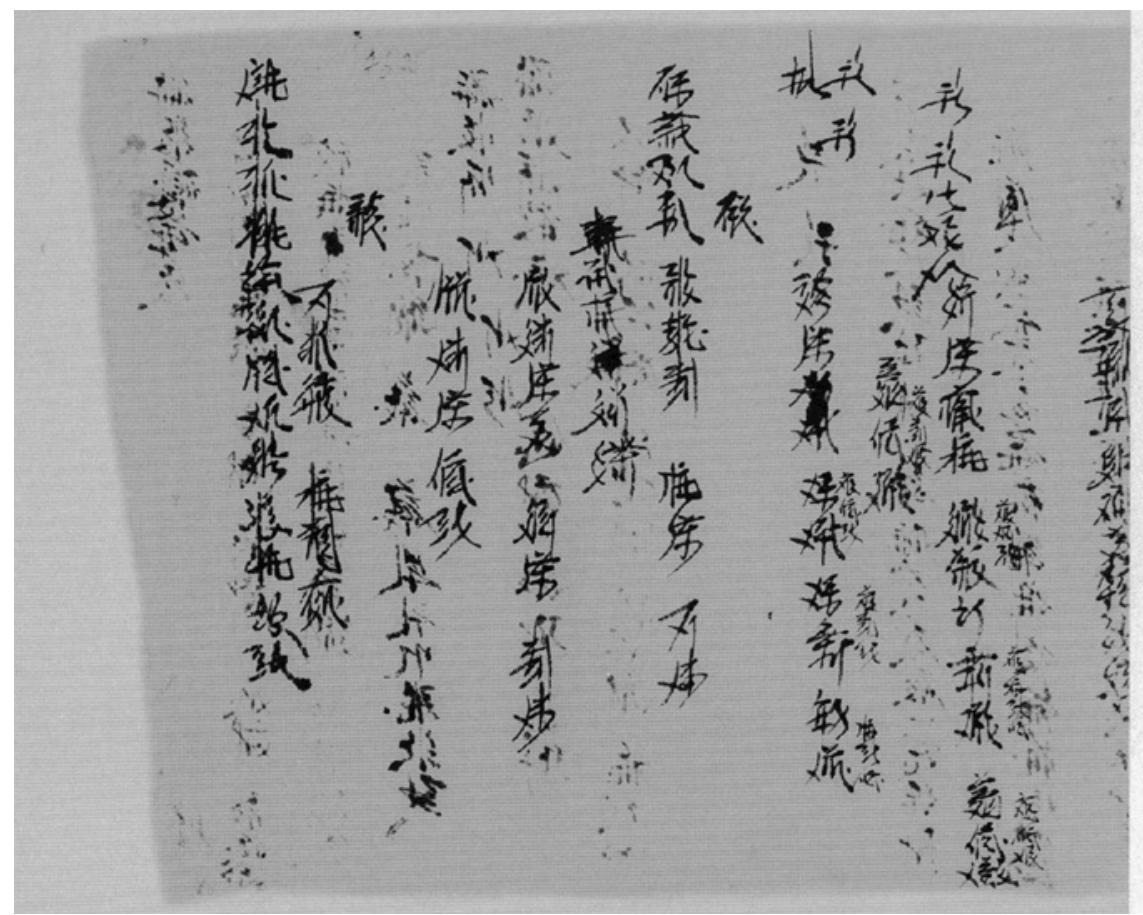

FIGURE 26 Инв. No. 7629-1: Self-reports (shoushi) (2)

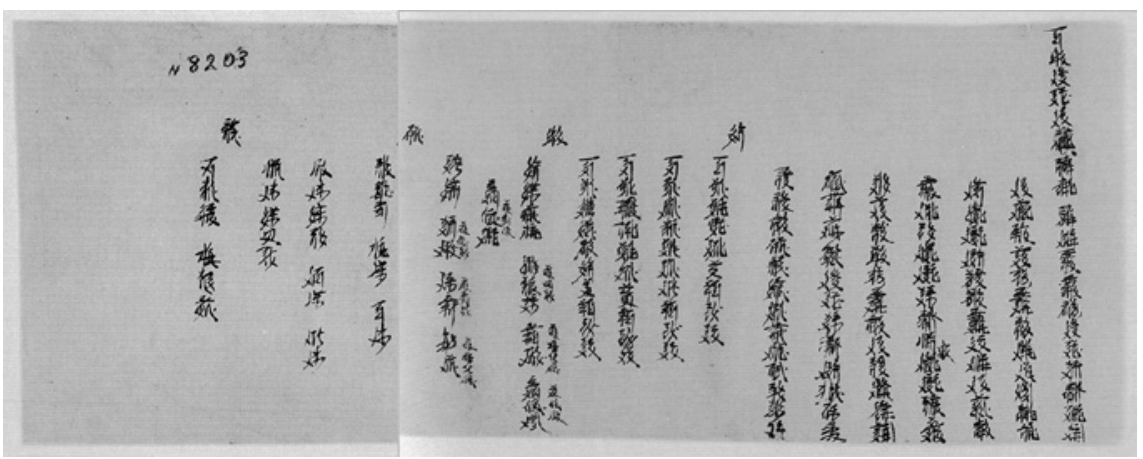

FIGURE 27 Инв. No. 8203: Household self-report

paper, $20.2 \mathrm{~cm}$ long and $53.6 \mathrm{~cm}$ wide, with 22 lines of text and 3 lines of small characters noting the age of the person next to each name. ${ }^{62}$

The patriarch of this household formerly held the title of "standard soldier of the Imperial Sentinels." The "imperial sentinel," which literally translates

62 Russian Collection of Khara-Khoto Manuscripts, vol. 14, pp. 256-257. 
as "front, internal guard," is the title of a Tangut soldier or official who both watches over the imperial household (the private and internal part of the palace housing all the wives and concubines of the emperor and his families) and is sometimes sent out to preside over civil affairs. A "standard soldier" is the main combat soldier in a chao, the most basic unit of the Tangut military. His assistant is an associate or assistant "main force," and the person bearing the burden or responsibility for miscellaneous physical labour is called the "burden man." This is a rather literal English translation of the shoushi Khara-Khoto Инв. No. 8203:

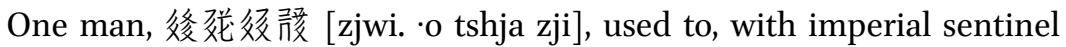

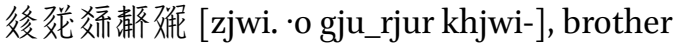

挍㒸 [tshja wja], [used to] be in one unit of chao. First because [he was] physically weak, under

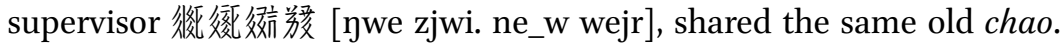
挍恶 [tshja wja] and

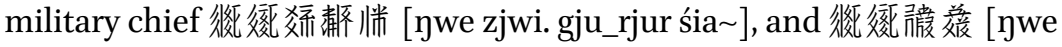
zjwi. pa rya]

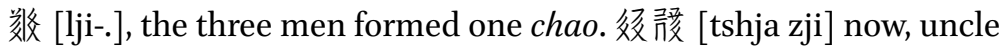

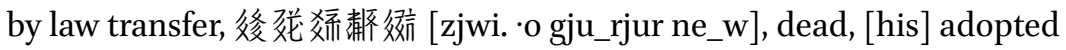
son. All the livestock are clear, as listed below:

Land:

One patch bordering the new canal, sowed seven dan, place.

One patch bordering Lüyi canal, sowed six dan, place.

One patch bordering Xipan canal, sowed seven dan, place.

One patch, mixed lands at the field's opening, sowed seven dan, place Persons:

Age forty age twenty-five age five

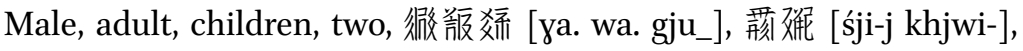
兴微濰 [śja. lhji. bie_j]

Age three

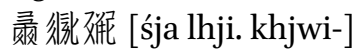

Woman, adult

Age fifty age thirty age twenty-five

[gju_mja] 效[gju_kie.] 㮄㥞 [sa tsjij]

Livestock:

Camels, three, two adults, one young (calf)

Cows, adults and young ten, four adults six youngsters (calves)

Sheep, adults and young eighty 


\section{Properties}

One blanket, two rolls of knots. ${ }^{63}$

This document declares the origin and history of the patriarch's military chao, the population size, and property ownership of the household. It provides details on the precise location (in terms of the four borders) and the amounts of his land, the names of family members, their age, the types and quantities of livestock, as well as other properties of considerable value. It is an important source for studies on both Tangut military (i.e., the chao system) and families.

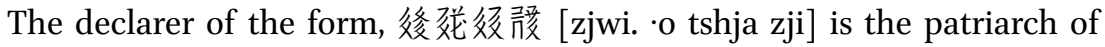

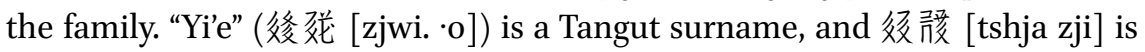
his given name. He may have been re-registering his household, along with his land, family members and livestock, as the foster son of his uncle Yi'e "the

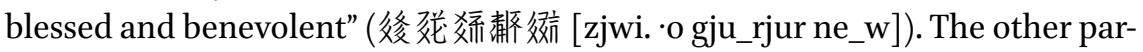

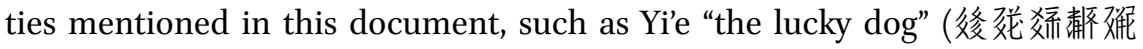

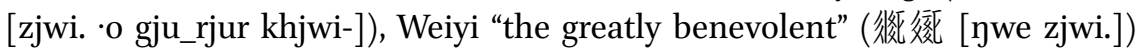

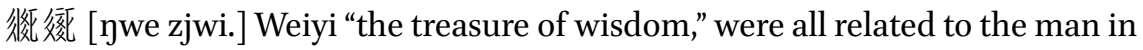
one way or another, and their names suggest that all of them were members of Dangxiang Tangut clans.

An analysis of the self-reports Khara-Khoto Инв. No. 7629-1 and Инв. No. 8203 yields some interesting numbers: We know that the family has four patches of farmlands, three of which were each large enough for seven dan of seeds, and one fit for six dan of seeds. The corpus of Tangut social documents reveals a variety of ways to measure land in the Tangut tradition, in addition to the Chinese $m u\left(614.4 \mathrm{~m}^{2}\right)$ and qing (10o $\mathrm{mu}$, or 15.18 acre). The Tanguts evaluated the size of land by the amount of seeds to be sowed. This measurement is adopted in the accounts of water taxes, contracts of land sales, and land lease excavated in Khara-Khoto. It is quite similar to the Tibetan practice of measuring land by the amount of seeds (in grams) that could be sowed in it. I have concluded, based on some statistical studies on the measurement of weight, that 1 hú $\left(5_{1} \mathrm{~L}, 1 / 2\right.$ dan) of seeds is roughly equivalent to 10 Tangut $m u$ (2.4 Song $m u$ ) of farmlands. ${ }^{64}$ Given this family's land in terms of 27 dan of seeds, they owned about 270 Tangut $m u$ farmlands.

63 藏 [xjwi-], unclear in meaning, is translated as "knot."

64 Shi, Jinbo. “Xixia Duliangheng Chuyi” [西夏度量衡忽議] “Some Initial Discussions on the Tangut System of Measurement" Journal of Guyuan Teacher's College [固原師專 學報], now Journal of Ningxia Normal University, issue 2, 2002. 


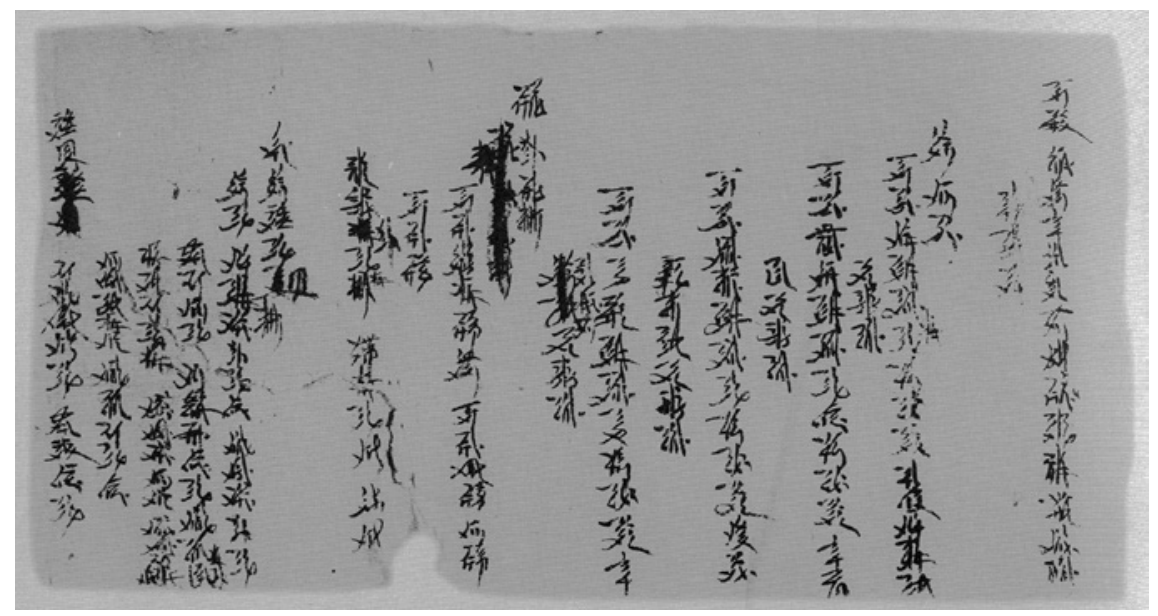

FIGURE 28 Инв. No. 7893-9: Household self-report

In addition to the patriarch himself, there are 2 adult males ( 40 and 25 years old, respectively), 2 boys ( 5 and 3 years old), and 3 adult females (5०, 30 and 25 years old) in this rather large family. On average, each family member owns 3.37 dan seeds of land-equivalent to 33.7 Tangut $m u$. Their wealth is also seen in the possession of 3 camels, 10 cows and 8 o sheep. The only missing information seems to be the family members' relationships to each other.

Another self-report (shoushi), Khara-Khoto Инв. No. 7893-9, records the data on the household of a mid-level military officer. It is written on hemp paper, $20.2 \mathrm{~cm}$ long and $39.8 \mathrm{~cm}$ wide, with 23 lines in Tangut cursive script and some damages near the end. ${ }^{65}$

This is an English translation of the document:

One household, xingjian Liang? Zhu, owned livestock, properties are registered and listed below:

Land, four patches:

One patch, borders Yang canal, fit to sow twenty dan, borders 羓胲 维效学 [-ja xwa nji_j lji-.j wejr] (place)

One patch, borders Daoli canal, fit to sow fifteen dan, borders 倠范 微 [ljow kie.j bie_j] (place)

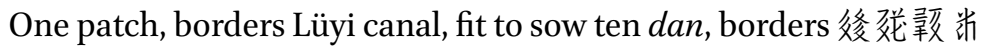
唼 [zjwi. o tsja tsji- wejr] (place)

65 Russian Collection of Khara-Khoto Manuscripts, vol. 14, p. 213. 
One patch, borders Qihu canal, fit to sow seven dan, borders 纱颓? [ljow njij ?] (place)

Of the three horses (livestock):

One stallion of two teeth, one mare of four teeth

One foal

Camels thirty-two, adults twenty-six, calves six

Of the eighteen persons, male and female:

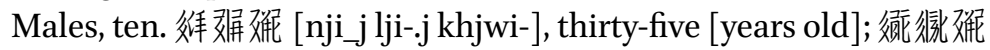
[tśjow lhji. khjwi-], thirty.

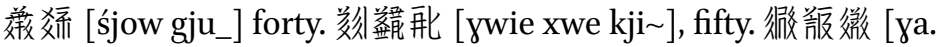
wa. bie_j], thirty.

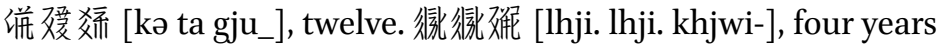
old. 佌微效 [tśjow lhji. gju_]

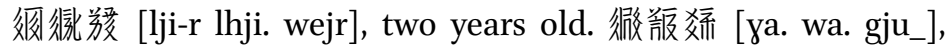
fifteen.

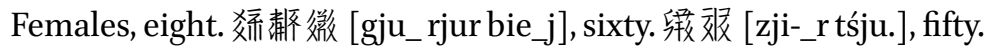

Xingjian (a local supervisor in the military) is lower in rank than bianjianjiao (a secretary, magistrate or censor), but higher than yingneng and liliu chiefs, and certainly high enough to be furnished with military tallies and signs. ${ }^{66}$ We could tell from the population and wealth of this household that it is well-established and well-to-do. The family owns four patches of lands, the sizes of which are: 20 dan, 15 dan, 10 dan and 7 dan, totalling $5^{2}$ dan in terms of sowed seeds. They also own 3 horses and 22 camels—not a small amount for a local family. The family comprises 19 members: 10 males including the patriarch (five are adults, three children, and one unclear) and 8 females (though only records on 2 of them, both adults, still remain legible). It is obviously a large and prosperous family, whose 19 members own $5^{2}$ dan seeds (in size) of land, about the equivalent of $520 \mathrm{mu}$ (approximately 86 acres), and on average $22.8 \mathrm{mu}$ (approximately 3.8 acres) of farmlands per person.

Although data in both this and the previous form seem to suggest that the Tanguts enjoyed vast farmlands, it should be noted that Khara-Khoto is far up in the northwest, where land is expansive and scantly populated. Moreover, the two families certainly do have some social connections and considerable wealth. They are by no means representative of the many impoverished peasants who presumably owned much less land.

66 Revised Laws of Heavenly Prosperity 6, p. 266. 


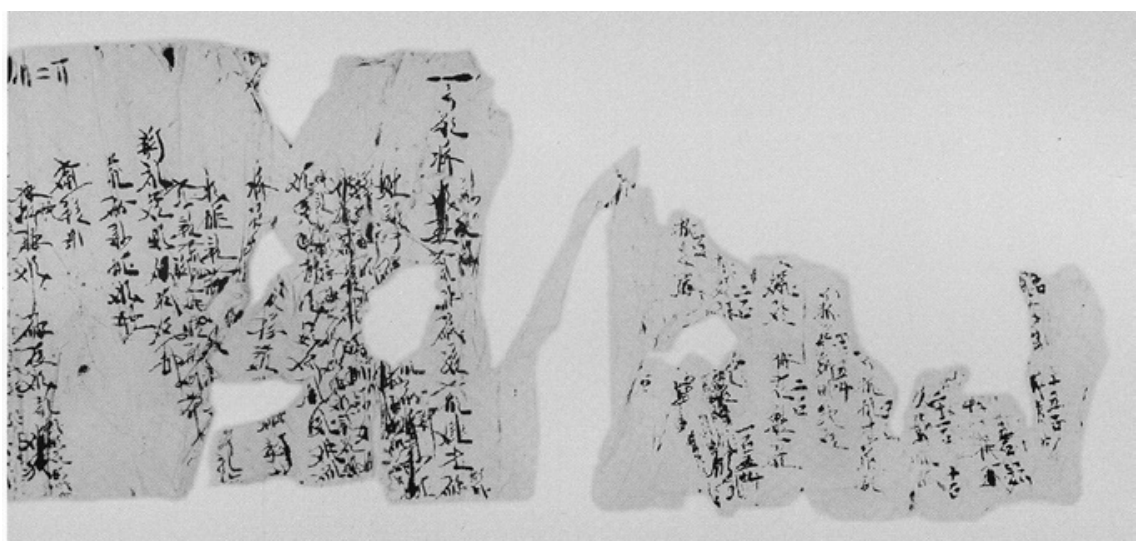

FIGURE 29 Инв. No. 4761-10V: Household self-report (1)

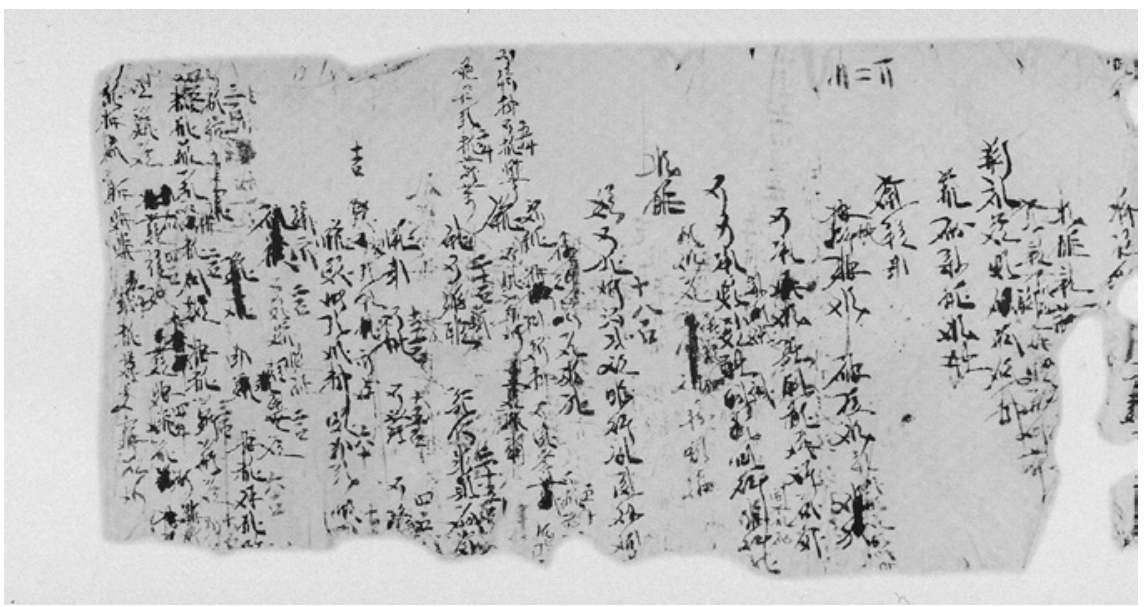

FIGURE 30 Инв. No. 4761-10V: Household self-report (2)

There is also a bilingual fragment of a self-report, Инв. No. $4761-10 \mathrm{~V}$, handwritten on hemp paper, $19 \mathrm{~cm}$ long and $70.8 \mathrm{~cm}$ wide, with $5^{6}$ lines in cursive Tangut, as well as occasional markings and corrections. ${ }^{67}$

This self-report is fragmented and blurred, and the Tangut text is difficult to read. The patriarch of the household is Hun, 汧 [xwe ] (渾), one of the major Han names in the northwest. So, it could have been because the family was Han that they labeled key words in Chinese, hence the Tangut-Chinese bilingual self-report.

67 Russian Collection of Khara-Khoto Manuscripts, vol. 13, p. 27 o. 
Apart from being bilingual, the shoushi is also noted for the following features:

1. Standard and Assistant Soldiers Listed. As we know, Tangut household and military registers are closely associated. In this document one standard soldier and three assistant soldiers within the family are identified, details rarely and for the first time seen in self-reports.

2. Numerous Items of Properties. Among the registered properties, in addition to farmlands and livestock, there are also houses and clothes listed separately. It is in this way more meticulously recorded than the Tangut self-report we have already seen.

3. Values of Noted Properties. When registering one's properties, the declarants sometimes write down not only the titles of the property but also its estimated value in Chinese right next to the item. The values of properties are commonly evaluated in terms of grains in dan. For example, a side note to "one patch of land, the place where six dan may be sowed" reads in Chinese, "eighteen dan," which is likely to be the value of this patch of land. Another example is the note in Chinese "twenty dan" written to the side of a mentioned horse, to denote the monetary value or market price of the concerned horse. Likewise, "twenty-five dan" noted next to a "full-teethed" (mature) camel informs us of the value of the camel. And "fifteen dan," "fifteen dan" and "four dan" written in Chinese by the side of the mentioning of three cows are probably their respective prices. ${ }^{68}$ Also, such labels as "ten dan" for a property, and "two dan," "three dan," "six dan" and "four dan" for clothes are all listings of their prices.

But the prices listed above tend to be higher than those indicated in contracts of land and livestock sales also excavated in Khara-Khoto. ${ }^{69}$ One may explain this gap by speculating that owners of properties sold their lands and livestock in a hurry, or out of emergencies, and therefore had to lower their prices to process the transactions and receive the payments in time.

\section{Analysis of Khara-Khoto Household Registers}

Household registers excavated in Khara-Khoto shed light on the region's demographics under the Tangut regime, with which we may inquire into many social realities of the Khara-Khoto city. These surviving manuscripts are also precious

68 Compared to prices in Khara-Khoto livestock sales contracts, the prices of horses, camels and cows here seem be rather high.

69 See Chapter 7 for more on contracts of land sale and livestock sale. 
because they alone tell us about the lives of the Tanguts at the bottom of the social hierarchy.

First, the Khara-Khoto household accounts are evidence of a highly developed household registration system in Western Xia. Registers are referred to as 涨 [dźjij] in Revised Laws of Heavenly Prosperity, which could be either household or military records. Household registration played important roles in the regime. For example, in the case of an indicted adopted son, courts of law considered pursuing charges on his family members based on whether the criminal was registered under the household of his biological parents or his foster parents. ${ }^{70}$ Revised Laws of Heavenly Prosperity require that Tangut peasant families report demographic changes in their households on time, to avoid any inaccuracies and confusions, and in this way to "keep the records clean and updated every three years."71 On the other hand, registers were directly linked to land taxes. These household records show that the Tanguts had already practiced a certain kind of census, and, after the Chinese tradition, updated their statistics every three years. It is also interesting to note that the data on liliu and jia as shown on the actual registers correspond accurately to the legislations in Revised Laws of Heavenly Prosperity. This showcases how the Tangut legal code was not only theoretically sophisticated, but systematically enforced.

Secondly, the archaeological finds in Khara-Khoto have furnished us with diverse materials, not only household registers but also accounts and forms declared by families (shoushi). Some of them are more elaborate than others. Some are more demographical, others more concerned with data on grain taxes, livestock and enlisted soldiers. In short, the Tangut registers are a microcosm of the diverse registration in medieval China.

At last, I should mention that the Khara-Khoto documents are rich in information, with names of patriarchs, all family members identified by gender, age and their relationships to the patriarch of the household. Sometimes even their specific ages at the time of the registration are given to us. More exhaustive is the content of a self-self-report, or shoushi, which reports the origin of junchao in the family, the identities of the patriarch, family members, owned lands, livestock and assets, even houses and clothes. Occasionally, properties such as land, livestock and clothes are evaluated in terms of grains, data that would enable us to estimate the commodity prices in the area. Therefore, that these comprehensive and manifold Tangut registers and accounts survived to this day is fortuitous for modern historians interested in Tangut families and

$70 \quad$ Revised Laws of Heavenly Prosperity 1, pp. 112-113.

71 Revised Laws of Heavenly Prosperity 15, p. 515. 
society. They occupy an extraordinary seat in the hall of medieval archives. Thanks to these documents, it has for the first time become possible to carry out rigorous inquiries into many previously unknown topics on the social conditions of Western Xia.

For example, the Russian Khara-Khoto manuscript Инв. No. 6342-1 tells us the population of 28 households to be 89 in total, which is on average 3.18 per household. Families appear to be quite small, for 10 of them are families of two comprised of only a man and his wife, which are $35.7 \%$ of the total number of households. This phenomenon deserves our attention. It could be that men leave to found their own household as soon as they are married. There are, moreover, 10 of what we may call 'nuclear families' - a couple and their children-also $35.7 \%$ of the total number. Given that this is the default pattern among youthful families, the percentage may appear to be small. Only one 'stem family' - with three generations living in the same household - has been identified. By contrast, households (2), (5) and (13) are single-parent families, constituting $11 \%$ of the total. In each of these three cases, an adult woman alone raises the children: one, two and three, respectively. The single mother in household (2) is identified as widowed. It is of legal importance that the families, though deprived of a patriarch or other adult males, still have boys: one boy, a boy and a girl, and two boys, respectively. According to Revised Laws of Heavenly Prosperity:

If all men of a household have perished, the law considers the family to be broken in its lineage. As for the properties belonging to the household, such as livestock, grain, treasures, house and lands, if there are surviving wives, daughters and sisters of the dead, as well as the married daughters and unmarried in-laws, let the wife gather the livestock, grains, and treasures, so that the women may receive their dowries as needed, according to the laws; but the rest of the livestock, grain, and treasures are not in the wife's disposal. They are, instead, to be monitored and managed in collaboration with another household that is close in lineage. If the women remarry or die, half of the properties they leave behind are to be distributed as dowries to the living daughters and sisters in the household in accordance with the prescribed laws mentioned above, with an increase to the sum; whereas the other half of the properties should be granted to different houses that do not share the same livestock, but are close in lineage to the descendants of grandparents, parents, uncles, aunts, brothers, nephews and grandsons. ${ }^{72}$ 
In other words, a household without male family members is "broken in lineage" - its properties are not inherited by the widow. Such a family barely survives in the legal sense of the term. The three families mentioned above, however, are not 'depleted' yet, thanks to the presence of the boys. They still have a chance to struggle and support themselves.

Most male heads of households have two-character surnames, whilst others have monosyllabic family names. Historically, traditional Tangut clans give themselves compound surnames. Some examples from the documents

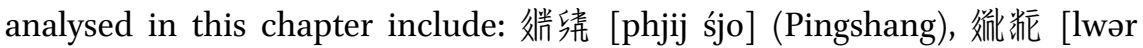

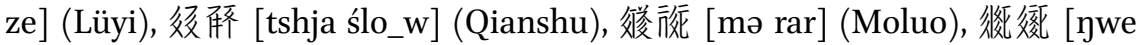
zjwi.] (Weiyi), 嚆㣪 [mjij pu.] (Mingbu), 微俢 [gjwi- dji] (Judi), 䍪務 [-ja ·jiw]

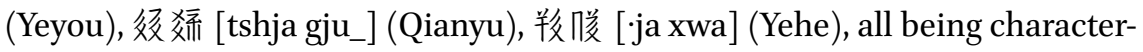
ically Dangxiang-Tangut family names. Three heads of households are named Lüyi, three Judi, two Qianshu, and two Weiyi. The name Liang is a more complicated story to tell. When it comes to Tangut royalties, the maiden name Liang often refers to the elder Empress Liang - wife of Liangzuo (Yizong), the second emperor of the Tangut Empire-and the younger Empress Liangwife of Bingchang, the third emperor of Western Xia. Although there are Han Chinese Liangs, the Tangut classic Golden Fragments lists 'Liang' as one of the Fan (Tangut) surnames. ${ }^{73}$ The name "Le," rather unlikely to be of Han origins, might be an abbreviation of the Tangut name "Gule." More research is due to solve this and other riddles. Compound names such as 释龍 [mja dzow]

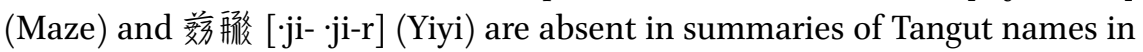
the Assorted Words, the Golden Fragments, or any other surviving Tangut manuscript. So, they may be newly-discovered Tangut surnames. Obviously, there are also a number of Han Chinese names in household registers, such as Yang, Hun, Pan, Luo and Han. Still, the documents are dominated by Fan names. In other words, households in this area of Khara-Khoto were mostly ethnic Tanguts. Given that no pattern of surname 'clusters' has been discerned, scholars could establish the weakness, if not absence, of family-based, clan-based domination at the local level. That is to say, ordinary Tangut villages might by this time have already evolved beyond or simply abandoned the shackles of clan-based social organisations. Instead, they formed mixed communities of different surnames and ethnicities. Historically, this was especially the case in mixed economies of farming and pasturing, where it is much more common to live alongside, and even to intermarry with Fan and Han neighbours.

73 Nie, Hongyin and Shi, Jinbo. “Xixiawenben Suijin Yanjiu” [西夏文本碎金研究]: “A Study of the Tangut Golden Fragments" in Ningxia Daxue Xuebao [寧夏大學學報]: Journal of Ningxia University (Humanities \& Social Sciences Edition), issue 2, 1995. 
There are, however, 'clusters' of given names, if not surnames. And it is here that the ingenuity and creativity of the Tangut mind is on full display. Some names pray for blessings and peace: 胆乘務 [zjo. dźjo jiw] (to enjoy longev-

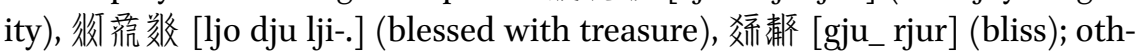

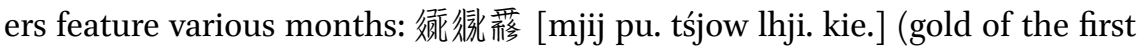

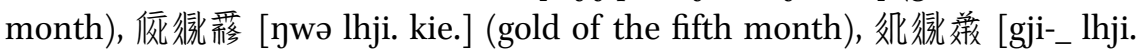
śjow] (iron of the ninth month), 挦微瓶 [śja lhji. wejr] (prosperity of the tenth month). They could well be the months in which the children are born, though so far, there is no conclusive evidence in support of hypothesis. Still others are

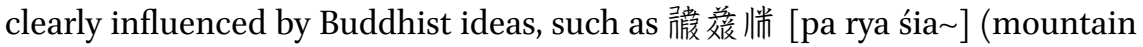

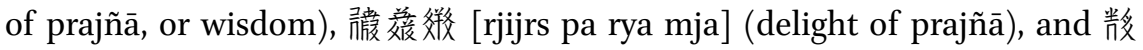
敚倄 [so. lji-. wejr] (flourishing of the triratna, or 'three treasures'). There are also some curious names with derogatory epithets, or names of animals that

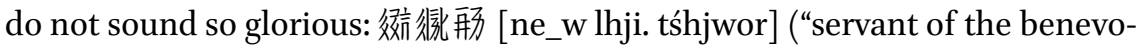

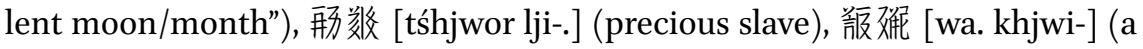

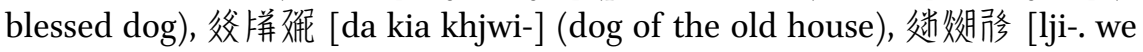
.jiw] (with a donkey), 徽涭 [dzju. we] (rainbird). Even women are given such

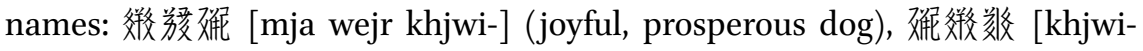
mja lji-.] (dog, lady, treasure). We know for certain that in Chinese folk culture, a derogatory name is thought to calm the jealousies of spirits and ghosts, thereby increasing the chance of the child's survival. Whether the Tanguts thought similarly is up for debate. Another revelation of the registers is that Tangut siblings rarely share "generation names." Quite the contrary, fathers and sons, mothers, and daughters do not shun the same characters in their names, despite their generational gap. An obvious example is household (10), where the names of the father 众栟嗳 [da kia wejr] (prosperity of the old house) and

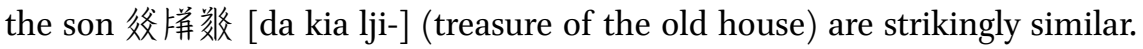
Likewise, in household (28), the mother 父拼稀 [da kia mja] (delight of the old house) and the son 父併烽 [da kia ne_w] (the benevolent old house) share two overlapping characters. Apparently, it is no offense to the seniors to be 'ranked' the same as their children.

Although the majority of Khara-Khoto residents seem to be ethnic Tanguts, and the registers suggest that most marriages are between Tanguts families, intermarriage was by no means a rarity. In household (6), for example, the wife of 绞解敬效 [tshja ślo_w wa gju_] has the maiden name 'Jiao' (㸚 [tsew]); Weiyi "the rainbird" in household (9) is married to lady 'Luo'; in (27), the wife of

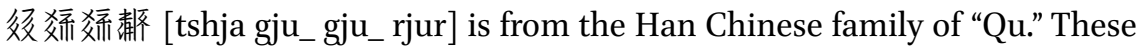
inter-ethnic marriages registered in official documents show that there was no legal barrier to Fan-Han intermarriage.

Polygamy is occasionally on display in the registers. In most cases, one man is married to two wives. In Household (23), for instance, there are two wives 
and two adult males in the family. But it remains unclear whether each man is married to one woman, or if one of the brothers is married to two wives. There is no doubt, however, that in household (27), the patriarch and sole adult

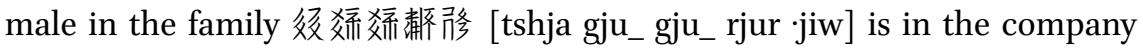

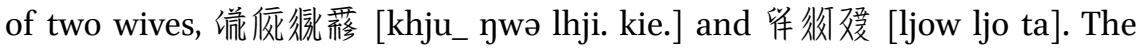
Tangut law code the Revised Laws of Heavenly Prosperity, especially in Book II on family relations, frequently refers to the "secondary mother" - in the sense of a "father's concubine" (equivalent to the Chinese shumu) -in regulations on mourning apparels honouring the deaths of family members. According to the laws, children are obliged to observe mourning rituals for their parents and "father's concubine" (considered a "secondary mother") for three years. ${ }^{74}$ In a way, Khara-Khoto social documents have verified the statements in the legal code, showing for certain that polygamy did exist in Western Xia. Previously, we only knew for a fact that Tangut emperors married multiple wives. Now, Khara-Khoto household registers convince us that commoners also engaged in this practice.

One of the two registers that mention the mother and daughter-in-law is worth some additional attention. In household (14), two adult females, the mother and wife of the patriarch, share an identical maiden name 解倫 [phiow tshji-j] (Pangqing). In other words, the mother-in-law is the aunt of the daughter-in-law, and the father-in-law of the patriarch is also his uncle. This is a case of cross-cousin marriage, a widespread social phenomenon in Tangut communities. In the Tangut language, the word for "marry" is a homophone of "nephew-uncle," and "mother-in-law" is homophonic to "aunt." This is a telling piece of historical-linguistic evidence on the social practice of cross-cousin marriage. ${ }^{75}$ The custom was also present in the imperial court. After all, the first emperor of Western Xia, Li Yuanhao, the second emperor Liangzuo, and third emperor Bingchang all married daughters of their maternal uncles. The kind of cross-cousin marriage as practiced in Western Xia was in fact an ancient marital custom, once popular amongst many ethnic communities. Therefore, the surfacing of specific scenarios of cross-cousin marriage from the Tangut household registers is neither surprising nor coincidental.

Western Xia is a multi-ethnic empire. Each ethnic group is organised along the lines of social classes. For the same reason, family structures are highly diverse. Overall, Tangut families are patriarchal. By the Revised Laws of

74 Revised Laws of Heavenly Prosperity 2, pp. 134-135.

75 Shi, Jinbo, “Xixiayu de Maimai he Jiaqu” [西夏語的買賣和嫁娶]: “Tangut Words for 'Buy,' 'Sell,' ‘marry (to a husband), 'marry (to a wife).” Minzu Yuwen [民族語文]: Minority Languages of China, issue 4, 1995 . 
Heavenly Prosperity, a couple may jointly form a "co-habited household" with their elders: great grandparents, grandparents, parents and unmarried aunts, kinsmen of the same generation, such as unseparated brothers and unmarried sisters, as well as the youths: sons, daughters-in-law, unmarried daughters, grandsons and granddaughters. Of course, a family comprised of all the above kinships is rare, if not non-existent. Most households are only parts and branches of their extended family tree. The demographics disclosed in the self-reports (shoushi) reflect the diversity and complexity of Tangut families in the Khara-Khoto area. In short, the excavation of household registers in Khara-Khoto has furnished us with sources of unprecedented depth and detail, and greatly advanced our knowledge in many aspects of the Tangut society. 